\title{
Afeto e método em Havana
}

DOI: https://doi.org/10.22409/pragmatizes.v10i19.42980

\section{Marcelo Neder-Cerqueira ${ }^{1}$}

Resumo: Trata-se de um ensaio em primeira pessoa relatando a experiência de pesquisa de campo, realizada em Havana, sobre a obra do escritor cubano Alejo Carpentier. O ensaio articula a reflexão autobiográfica com algumas hipóteses desenvolvidas ao longo da pesquisa. Com uma narrativa fácil e envolvente, pretende-se trazer uma imagem realista da pesquisa científica no campo das humanidades, despertando o interesse pela aventura da imaginação sociológica.

Palavras-chaves: Alejo Carpentier; América Latina; Literatura; Metodologia; Ensaio.

\section{"Filin" y método en La Havana}

Resumen: Es un ensayo en primera persona sobre la experiencia de la investigación de campo, realizada en La Habana, sobre la obra del escritor cubano Alejo Carpentier. El ensayo articula la reflexión autobiográfica con algunas hipótesis desarrolladas durante la investigación. Con una narrativa fácil y atractiva, tiene la intención de traer una imagen realista de la investigación científica en el campo de las humanidades, despertando interés en la aventura de la imaginación sociológica.

Palabras claves: Alejo Carpentier; América Latina; Literatura; Metodologia; Ensayo.

\section{"Filin" and method in Havana}

Abstract: This article is a first-person essay that talks about the field research experience, conducted in Havana, on the work of Cuban writer Alejo Carpentier. The essay articulates the autobiographical reflection with some hypotheses developed during the research. With an easy and engaging narrative, it is intended to bring a realistic image of scientific research in the field of humanities, awakening interest in the adventure of the sociological imagination.

Keywords: Alejo Carpentier; Latin America; Literature; Method; Essay.

\footnotetext{
${ }^{1}$ Marcelo Neder Cerqueira. Professor e pós-doutorando junto ao Programa de Pós-Graduação Cultura e Territorialidades da Universidade Federal Fluminense (PPCULT/UFF), com financiamento da Fundação de Amparo à Pesquisa do Estado do Rio de Janeiro (FAPERJ), Programa de PósDoutorado Nota Dez. Brasil. E-mail: marcelonedercerqueira@gmail.com - https://orcid.org/00000002-4502-1644
} 


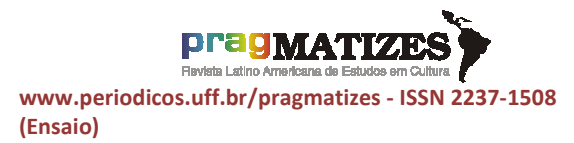
(Ensaio)

\section{Afeto e método em Havana}

Coloquei o despertador para nove horas da manhã, mas acordei meia hora antes. Ignácio já havia preparado tudo e me esperava na sala. $O$ rádio estava ligado. 0 ventilador, posicionado a meia distância, soprava uma brisa fria no sentido do corredor que levava à outra sala.Tudo bem calculado. Sobre a mesa de toalha verde musgo, uma rodela gorducha de abacaxi, duas tiras de mamão e cinco fatias de goiaba. Ao lado, uma jarra de suco, também de goiaba, da fruta, mais um cesto de pães e um pires de louça colonial com três quadrados de manteiga. "Buenos dias!" Ignácio rapidamente se levantou da poltrona e foi na direção da pequena cozinha. O café já estava pronto, passado em uma cafeteira italiana de ferro que pousava à beira do fogo aceso para manter-se aquecida. Enquanto conversávamos, ele me trouxe dois huevos revueltos, um pote com marmelada e um pratinho com uma tira de queijo e uma fatia de mortadela.

“(..) por la celebración del fin del año (...) diferentes programas culturales (...) de los quinhentos años de La Havana (...) Rádio Rebelde (...) el año sessenta y uno de la Revolución (...)". O suco estava uma delícia, denso e sem muito açúcar. Fazem o suco batido no liquidificador, sem casca, depois passam no coador para tirar as sementes. O suco fica denso como uma vitamina. Agora tocava uma balada com ares flashback eu tentava discernir o timbre da voz de Silvio Rodrigues, embora preferisse Pablo Milanés. O café estava precioso e eu sabia que por todos aqueles dias eu poderia desfrutar de um café bem passado, a qualquer hora e sem açúcar. Havia ainda trazido na mala dois pacotes de café do Brasil, por garantia, mas também como um gesto de agradável intercâmbio com Ignácio. Em Cuba toma-se cafés e sucos em geral como no Maranhão; tudo já adoçado com muito açúcar. Lembrei da tese vulgar de que no Rio a cultura fitness já havia praticamente afastado o açúcar previamente inserido nas bebidas vendidas em lanchonetes e bares. O mesmo não se via quando se viajava para o interior ou norte do Brasil. Ignácio já estava de saída quando chegou enfim Carmen com um sorriso. "Hola, Marcelo, buenos dias! 
Viste que salió la programación del Festival?"

Estava previsto ficar hospedado no primeiro andar da casa de Carmen e Ignácio entre os dias 2 e 21 de dezembro. Carmen estava com um lenço amarrado na cabeça e uma juventude indestrutível para uma senhora de quase setenta anos. Uma casa cômoda, no elegante bairro Vedado, em La Havana, perto da Necrópole. A indicação foi do amigo Júlio Costantini - ele costuma omitir o segundo nome, César, que sucede o primeiro, assim como o último sobrenome: Júnior. Júlio é fotógrafo de cinema, um cidadão do mundo. Morou três anos em Cuba cursando a Escuela Internacional de Cine y Televisión (EICTV), em San Antonio de los Baños. A primeira vez que estive em Cuba, há dez anos atrás, em 2008, foi hospedando-se com ele na Escuela. Entretanto, dessa vez Júlio não pode estar a Cuba. Depois de um ano trabalhando na Califórnia, ele tinha que rodar uma película no Brasil e estaria livre apenas depois das festas. Eu havia planejado fazer a viagem de pesquisa de campo para Havana justamente no mês de dezembro, com esperança de "sincar" com a sua presença. Dezembro é inverno acima do Equador. Em Havana o clima é ameno, com dias ensolarados e noites frescas. É quando ocorre o Festival Internacional de Nuevo Cine Latinoamericano.

No Galeão, após fazer o checkin no voo noturno para Panamá, identifiquei pelo corredor 0 inconfundível Silvio Tendler. Ele estava em uma cadeira de rodas, bem arrumado, e exibia uma vasta cabeleira e barba prateada. Hesitei um pouco, mas fui na sua direção. "Oi, Silvio, vim te dar um abraço. Sou Marcelo, filho do Gisálio". "Ah... que maravilha! Crescemos juntos na mesma rua, em Vila Isabel". "Eu sei, por isso estou te dando um abraço, Silvio. Saudações!" Não queria incomodar e preferi me afastar amistosamente. Não precisava de mais detalhes, sabia que era um bom sinal. Será que ele também estaria voando para La Havana para participar do festival de cinema? Com certeza estaria no Festival com algum filme. Esperava encontrá-lo no avião, mas não o vi. Uma viagem longa e cansativa, pensei... Silvio deveria ter a idade de meu pai. Cresceram numa Vila Isabel de peladas de rua, torneios 
de futebol de botão e dramas pequeno burgueses rodrigueanos. A mesma Vila que seria reescrita por Aldir Blanc em suas crônicas e canções febris dos arredores da Rua dos Artistas.

Com Carmen e Ignácio eu tinha um quarto só para mim e, como não havia ninguém mais hospedado na casa, poderia desfrutar mais à vontade da sala, da varanda e da cozinha. Tinha a possibilidade de tomar café da manhã por três ou cinco CUCs - a moeda turística que equivale mais ou menos ao euro. Por cinco CUCs Ignácio prepararia um café completo, com huevos revueltos, queijo, harburguesa, dentre outras coisas; por três CUCs eu teria um café más sencillo. Amorosos e muito educados, Ignácio e Carmem tinham viajado o mundo, mas nunca deixaram Havana. Por cinco anos moraram em alguma região bem fria da antiga União Soviética. Desses lugares onde, durante inverno, para ir ao trabalho, tem-se que usar uma pá para tirar o gelo das rodas do carro. Tinham uma filha e - "el más importante agora", dizia Ignácio, sorrindo - um neto, que morava com a mãe e o esposo em Paris. Falavam russo e francês e preferiam receber em euros do que em
CUCs, pois planejavam uma visita à família no ano seguinte. Eu preferia fazer o meu próprio café da manhã, mas sabia que a oferta do serviço incrementaria os ganhos e os planos do casal. Fizemos então um acordo de alternar dia sim, dia não. Carmen disse a mim que, para eles, receber-me em casa era como receber um pouco do Júlio que eles tanto amavam.

Estava bem preparado para a viagem, tinha tudo que precisava. Poucas roupas - e leves -, documentos em dia, mil euros, uma sunga, dois isqueiros, o computador de trabalho com carregador e adaptador para tomadas, um extrato de própolis, um livro de suspense policial, Máscaras, de Leonardo Padura, o hidratante para mãos e unhas de costume, para prevenir a crônica psoríase nas mãos, a novela $A$ harpa e a sombra, última ficção de Alejo Carpentier, e a coletânea Poemas, do Maiakovski, traduzida e organizada por Boris Schnaiderman e os irmãos Augusto e Haroldo de Campos, presente do amigo Thiago Castanõn, excelente cantor e violonista, que trabalhava como professor substituto de teoria literária na UFRJ. Levava ainda uma carteira 


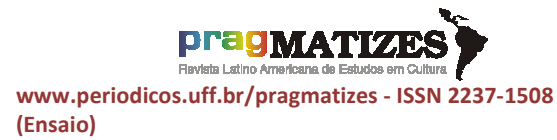

de tabaco suave destalado para enrolar, três rolos de papel higiênico duas folhas e o inseparável violão seis cordas.

Seriam dezenove dias em Havana, mas não tinha do que reclamar. Estava cercado de bens culturais, numa casa cômoda, e poderia desfrutar do tempo para produzir. Ficar bem sozinho e investir no autocuidado são recursos necessários para a construção da autonomia da vida e do pensamento crítico. O computador trazia ainda a possibilidade de acesso a textos, músicas e projetos em construção que poderia manejar. Trouxera junto comigo o violão de trabalho, um excelente Takamine que me foi emprestado há anos pelo amigo Ricardo Bormann quando partira então para fazer seu doutorado em Munique, na Alemanha. "Toma, fica com ele, eu não vou tocar mesmo e é melhor ficar com alguém que toque". Creio fazer mais de sete anos. Um instrumento bem regulado que se tornou parceiro nos bailes de forró pé de serra e trabalhos com música. Já havia tempo em que, por filosofia, deixara de levar comigo a "águia" - meu velho violão "de viagem" - um simples Egle, preto.
Isso porque não queria perder a forma e poderia aproveitar o tempo para compor e estudar também. Deve-se sempre ter um bom instrumento à mão. Ricardo se mudara de Munique e agora trabalhava como professor e pesquisador em Bremen, uma cidade universitária, decididamente mais alegre e acolhedora que Munique.

"Não vim fazer turismo", pensei, e lembrei imediatamente do "turismo aprendiz", de Mário de Andrade, ou do olhar de "turista cubano" que Carpentier lançou sobre Havana em suas Crônicas del regreso, após larga estadia na França na década de 1930. Lembrei também das Cartas de José Marti sobre cultura e política na Américas, muitas delas escritas desde Nova lorque; ou ainda da paixão febril do jovem Borges pelo arrabalde criollo e decadente de Buenos Aires, quando este retornara a sua cidade natal no começo da década de 1920, após longa estadia da família na Suíça e Espanha. Estava então em Havana para realizar parte da pesquisa de pósdoutorado financiada pela FAPERJ que empreendia junto ao PPCULT (Programa de Pós-Graduação em Cultura e Territorialidades), do Instituto de Artes e Comunicação Social da 
Universidade Federal Fluminense (IACS/UFF). A pesquisa incluía a obra de Alejo Carpentier e previa a visitação das duas unidades da Fundação que leva seu nome, além da Biblioteca Nacional José Martí.

Não é novidade que a condição de viajante anima o pensamento crítico e a imaginação sociológica. Edward Said fez do exílio metáfora para a condição intelectual. Octávio Paz, da condição de desterro, vocábulo latinoamericaníssimo. Guimarães Rosa narrou a travessia pelo hinterland brasileiro em sua dimensão natural, psicológica e sexual - o rio que baldeia a paixão de Riobaldo tem três margens e chama-se Urucuia. Não consigo deixar de lembrar do clássico TOKIO-GA, de Win Wenders, ou ainda o seu Lisbon History - gosto da ideia de um banho lusitano no olhar alemão. Aliás, Guimarães Rosa atuou como cônsul em Hamburgo, na Alemanha, entre 1938 e 1942 . Viveu os horrores da guerra e do irracionalismo político. Quando escreveu Grande-sertão: veredas, não hesitou em posicioná-lo junto ao Fausto, de Goethe,em diálogo com os avatares da crítica romântica alemã. Como músico, havia feito parte da companhia de teatro que encenara performances baseadas em trechos do Grande sertão no curso da caminhada cultural e ecológica Caminho do Sertão, pelo interior de Minas e Goiás. Atravessei o rio Urucuia com a trupe numa pequena balsa, meses antes, naquele mesmo 2019 - o rio que tinha a cor dos olhos de Diadorim. Não quero ser exaustivo. A operação de deslocamento configura-se como uma travessia corpórea e subjetiva psicossomática, por assim dizer. O ser humano é um mamífero migrante. Este movimento crítico me era familiar. Estranho foi reconhecer - mais uma vez - o efeito devastador do capital na economia de trocas simbólicas que permeiam a construção de mercadorias turísticas. Não por se tratar de uma ilha socialista, bloqueada, isolada. Justamente 0 contrário: o conceito hegemônico do turismo é devastador em qualquer lugar, até numa ilha socialista. Cria-se uma relação agressiva e violenta com o espaço, com a cultura e com as pessoas. Submete-se os bens culturais mais expressivos e originais a estereótipos rasos, sem alma e expressividade. Lembrei que em Barcelona 0 modelo de cidademercadoria parecia ter saturado por 


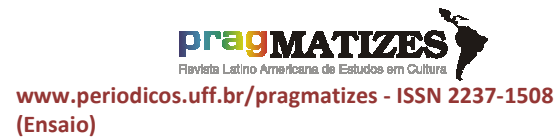

Iniciei a leitura de Máscaras, do Leonardo Padura. O detetive Mario Conde dá uma aula de método e investigação na Havana contemporânea - como sucede, bem verdade, na melhor tradição da literatura policial. Carlo Ginzburg desenvolveu 0 argumento da aproximação metodológica entre a narrativa policial e o ofício do historiador em Mitos, emblemas e sinais. Em $O$ juiz e o historiador, assim como em Relações de força, o historiador italiano retoma seus argumentos teórico-metodológicos enfatizando a importância da prova para a interpretação histórica e o enfrentamento do relativismo neoliberal. Para Ginzburg, os aportes epistemológicos da metodologia indiciária são feitos com o mesmo barro que resultou no método clínico da psicanálise. Embora com diferentes objetos, Ginzburg apresenta-os como ramos de uma mesma tradição crítica: afluentes de uma abordagem epistêmica que contempla a singularidade e que, a partir da leitura do contingente, do periférico, do sintoma ou do deslize, ensaia a compreensão da totalidade de um fenômeno histórico-social. Ginzburg 
opera o efeito de deslocamento e estranhamento na própria construção metodológica de seus argumentos.

$\mathrm{Na}$ coletânea Um mapa da ideologia, Slavoj Žižek sustenta em seu artigo a tese de que "Marx inventou o sintoma", como método de análise crítica da ideologia (o fetiche da mercadoria) visando a compreensão crítica da história em transformação no processo de consolidação da dominação burguesa. O método marxiano visa desarmar os artifícios ideológicos da economia política burguesa (suas crenças e dogmas) que sustentam e naturalizam a dominação na sociedade moderna, dita racional e científica. Para tanto, Marx se apropriou do vocábulo-chave fetiche, culturalmente referido ao processo colonial luso-brasileiro na costa ocidental da África, não para falar dos ritos religiosos africanos, mas para falar da superstição "religiosa" da economia política moderna em sua unidade mínima: a mercadoria. Isso em uma época em que africanos escravizados eram vendidos e traficados como... mercadorias. A palavra fetiche, vinda do português antigo, de origem latina, foi cuidadosamente escolhida por Marx para falar dos "elementos mágicos" da dominação capitalista. Efeito de deslocamento: como uma palavra "intrusa", Marx reverte o significante da "superstição", atribuído na época às sociedades consideradas "primitivas", para falar da violência simbólica e a exploração do trabalho no capitalismo moderno.

Para Žižek, todavia, o conceito de ideologia não poderia reduzir-se apenas a seus efeitos de "inversão" ou falseamento da realidade, como na fotografia, embora estes efeitos ilusórios não estejam de todo ausentes da ideologia. Para além de seus efeitos falseadores, movidos pela apreensão sempre parcial da realidade, e para além de certo elemento mágico ou "mentiroso" que incide na dominação política, a ideologia é estruturante da realidade, da linguagem e da organização social. Não há acesso à realidade histórica fora da ideologia. Não há "lugar fora" da disputa político-ideológica. Daí a importância do método de análise crítica. Isso não impede que a expressão da ideologia assuma em certos casos uma forma negativa prototípica - digamos, como expressão clichê do efeito de 
"inversão". Os Selectos, de Holguin, por exemplo, podem ser qualquer coisa, menos charutos selecionados. Ao contrário, são os puros mais populares, feitos em massa, e Holguin nunca teve tradição na produção de tabaco. Isso nos ensina também, com ironia, o detetive Mario Conde - que também de nobre não tem muita coisa, fora o ideal vulgar de honra masculina. Trata-se de um detetive comum, decadente e machista, no melhor estilo noir dos contos policiais de Raymond Chandler. Não que fosse necessário viver o personagem Mario Conde, de Leonardo Padura, para descobrir que os Selectos nada tem de selecionados. Compra-se os puros de Holguin por um peso de moeda nacional. Um autêntico Montecristo, número quatro, por sua vez, compra-se em CUCs por mais de cem vezes o valor de um Selecto.

Máscaras apresenta a Havana do Período Especial como uma Havana noir. Não apenas pelo submundo clandestino que se descortina, mas pelas máscaras que caem e pelo efeito narrativo da experiência das ruas - a vivência da cidade (e da história) vista "por baixo" que tanto fascinou Edward Thompson.
Cidade vista "por baixo"que também é cidade vista "pela sombra" ou "pela noite". Mario Conde sabe que não há como desvendar o caso sem transitar pelas sombras da cidade. A metáfora da luz funciona como crítica metodológica do próprio conceito de ideologia. Ele sabe do efeito de cegueira produzido pelo clarão da "cidade oficial". Chama atenção o heroico, embora melancólico, compromisso ético da personagem Mario Conde com seu ofício, com a prova, com o desvelar da verdade e comunicar essa verdade ao poder, mesmo que para isso tenha-se que pagar um preço. Ao que parece, nenhum cubano comum acredita que os Selectos, de Holguin, sejam charutos selecionados. Nesse caso, o caráter explícito da propaganda enganosa (a ideologia), configura uma relação verdadeira com essa mentira. O mesmo sucede em muitas outras pequenas experiências cubanas. Por sua vez, a sofisticação ideológica da dominação nas sociedades capitalistas de hoje está justamente na anulação de qualquer relação verdadeira que se estabelece com a mentira em troca de uma relação mentirosa com a mentira. Todos sabem que são vigiados e 
manipulados pelas redes sociais, por exemplo, mas fingem que não sabem. Žižek, em "Como Marx inventou o sintoma”, busca a compreensão dessa sofisticação da dominação ideológica no capitalismo pós-moderno a partir da "razão cínica" de Peter Sloterdijk.

Estava hospedado a meia hora a pé de uma das unidades da Fundación Alejo Carpentier. Precisamente a casa onde vivera 0 escritor com sua esposa, onde hoje funciona a oficina de pesquisa $e$ guarda-se a biblioteca pessoal do escritor, inclusive com materiais inéditos. A outra unidade da Fundación situa-se em Havana Vieja, em um quadrilátero turístico, onde realizam-se eventos e exposições: um casarão colonial destinado a funcionar como uma unidade promocional e cultural da obra de Carpentier. Eu havia chegado por volta das duas da tarde em Havana Vieja, mas o casarão já estava fechado. Abriria apenas no dia seguinte, às oito e meia. Optei por voltar pra casa caminhando, cortando a cidade pela avenida Carlos III. Uma senhora caminhada! $\mathrm{Na}$ saída do Barrio Chino divisei o Gran Templo Nacional Masónico de Cuba, um pouco antes de chegar na Plaza de La
Revolución. Tinha ainda algumas missões a cumprir: trocar dinheiro, arranjar algumas moedas nacionais, ver se já havia saído a programação completa do festival de cinema, identificar os comércios de frutas, comprar o cartão de internet pré-pago na lojinha da ETCSA que me daria acesso ao wi-fi das praças. Sentia saudades do Brasil e uma necessidade patológica de me comunicar com pessoas queridas.

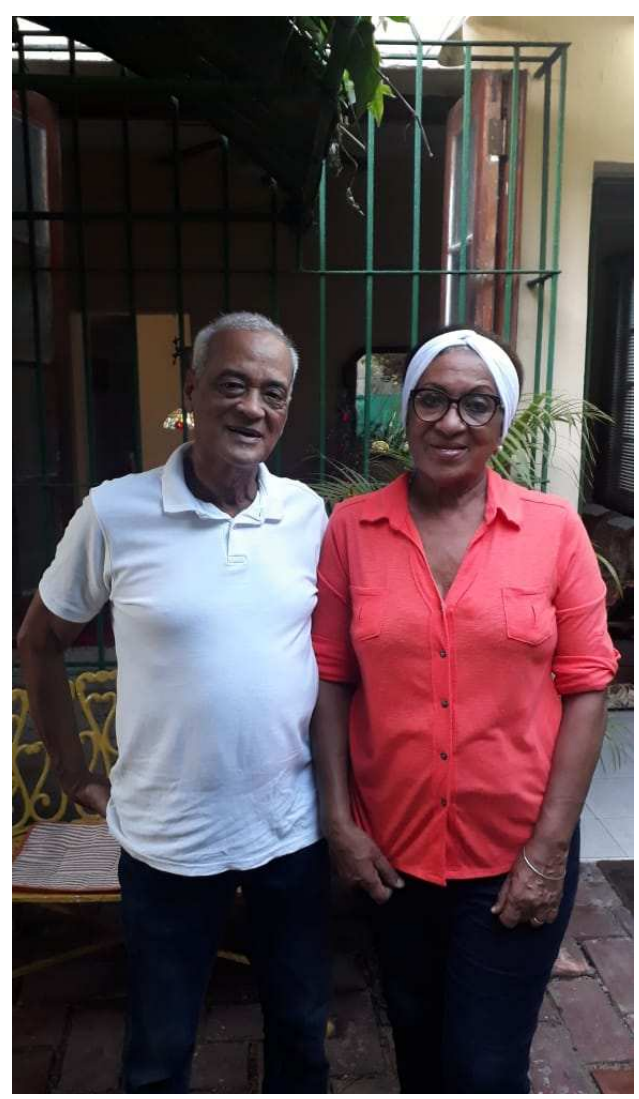

Carmen e Ignácio, em frente ao portão de sua casa, em Vedado, onde me hospedei durante a pesquisa de campo em $\mathrm{La}$ Havana, em dezembro de 2019. 
o dia seguinte, fui à outra unidade da Fundación Alejo Carpentier, em Vedado. Tinha o endereço previamente impresso nas mãos. Calle $\mathrm{E}$, entre 11 y 13 . Pelo caminho, suntuosas embaixadas de diferentes países. Mansões antigas reformadas com jardins cuidados, quando se podia vê-los através das grades e muros. Mesmo num bairro elegante, era preciso certo cuidado, olhando onde pisava pelas calçadas quebradas para não tropeçar, fugindo de uma eventual língua de esgoto a correr pelo canto das ruas. Não tinha medo, nem juízo de valor contra esgotos e calçadas quebradas. Isso também é Brasil ou qualquer "quebrada" em um lugar qualquer. Claro que ninguém gosta de esgoto e calçadas difíceis, menos ainda os idosos, embora seja bela e encantadora a estética do concreto rompido pela natureza implacável das raízes de árvores, ou o barro vermelho que rompe e sangra entre o concreto de Brasília. Há beleza até nos pequenos tomates que brotam perto de um cano ou língua da esquina. Aquela arquitetura da destruição e recauchutagem já fazia parte da normalidade cubana, mas de fato lembrava um sutil estado de guerra. $\mathrm{O}$ interessante é que estava em um bairro elegante de Havana, mal comparando, como Higienópolis, em São Paulo, ou Recoleta, em Buenos Aires. Em Higienópolis não se vê esgotos e calçadas quebradas, mas deve-se estar atento ao chão, driblando o campo minado de cocôs das dondocas. A embaixada chinesa parecia um palácio. A da Inglaterra era mássencilla. Numa daquelas mansões poderia estar a rica família de Alexis Arayán, que fora encontrado no Bosque de Havana, enforcado, travestido de Electra, com uma faixa de seda vermelha no pescoço e duas moedas no ânus... e no dia da Transfiguração de Cristo! Mario Conde era um policial com vocação frustrada de escritor, afeito ao rum, ao tabaco e certa nostalgia "romântica pósromântica" que uns classificariam como tipicamente criolla e masculina. Estranhamente percebi que eu também tinha meu caso para resolver por aquelas ruas, enquanto meu pensamento vagava, como gatos que pulam das caçambas de lixo. Haviam tantos gatos em Vedado quanto em Ponta Negra, em Natal, onde o vento faz a curva ao nordeste da América do Sul. 
Uma casa grande, antiga, com as paredes descascadas e escombros nas calçadas. Tinha um guarda sentado na frente da casa, atrás de uma mesa, era um senhor. "Hola, buenas tardes, aqui es la Fundación Alejo Carpentier?" Ele parecia não entender o que eu disse. Meu portunhol estava enferrujado, mas nem tanto. O senhor parecia não ouvir muito bem. Tentei explicar que era do Brasil, pesquisador da universidade pública, que estava estudando a obra de Carpentier, e como ele parecia continuar entendendo bem pouco do que dizia resolveu chamar alguém. Fui atendido pelo simpático Rafael, vicepresidente da Fundación. Muito solícito, ele conhecia a Universidade Federal Fluminense. Disse que me poria em contato com a bibliotecária. Infelizmente, ela não estava no dia. Segui seus passos pelo corredor. Pelos quartos: mesas com pilhas de livros, leituras em voz alta, papéis, funcionários para lá e para cá. Tinhase a impressão que os trabalhos de pesquisa e organização funcionavam a todo vapor. Fomos até sua sala, um dos quartos da antiga casa de Alejo Carpentier. Pelo corredor notei de relance o crucifixo de madeira com um sino colonial na parede. Rafael anotou um telefone sobre um papel rascunho em sua mesa e disse que telefonasse até às $10 \mathrm{~h}$ da manhã no dia seguinte para falar com a bibliotecária Margarita, solicitando então as direções e temas de interesse da pesquisa para que ela preparasse algum material de consulta. Não hesitou em perguntar-me à queima roupa qual era o enfoque da pesquisa. "Soy historiador e sociólogo estudioso da literatura latino-americana, con foco en los ensayos e ficciones de las vanguardias modernistas de los años 20 y 30 y adelante. Estoy trabajando con diferentes autores. En mi tesis de doctorado, he trabajado con Carpentier, Borges e Sérgio Buarque de Holanda". "Y Amado, no?" Referiase a Jorge Amado. "No... todavia no". "Bién..." Respondeu dando a entender que tal relação seria imprescindível. "Pero, ahora, estoy trabajando también com el boliviano Néstor Taboada Terán", completei. Ali mesmo em sua sala estava toda a biblioteca pessoal de Carpentier. Sobre sua mesa um laptop cacareco. Não seria possível ainda visitar a Fundación. Teria que ligar no dia seguinte. $\mathrm{Na}$ volta pra casa passei na ETCSA para comprar o 
cartão pré-pago de internet, mas tinha uma fila enorme e desisti. Fui ao Banco Metropolitano, mas tinha acabado de fechar a última pessoa da fila que dobrava a esquina. No Cine Charles Chaplin, na Avenida 23, consegui a programação dos filmes do Festival de Cinema. Não havia, entretanto, os horários dos filmes ainda, apenas as sinopses em letras miúdas. Os horários e salas onde passariam os filmes seriam divulgados apenas no dia-a-dia das exibições, em folhas de jornal coladas na parede dos cinemas. La muerte de um burocrata, do Titón, estava com uma cópia restaurada na sessão de clássicos. Eu conseguia sentir glamour e beleza nos Selectos, de Holguin, ou no tomate que brota em uma língua da esquina, mas jamais na burocracia.

O festival de cinema celebrava o centenário de Santiago Alvarez, importante figura do cine cubano, inovador da linguagem documental, que dirigiu o ICAIC ${ }^{2}$ por muitos anos. Procurei pelos filmes brasileiros. Já havia assistido o incrível Bacurau, de Kléber Mendonça. Divisei que passariam o Mariguella, do Wagner

\footnotetext{
${ }^{2}$ Nota do editor. ICAIC, Instituto Cubano del Arte e Industria Cinematográficos.
}

Moura, e o Três verões, da Kogut, que ainda estavam entrando no circuito comercial no Brasil. Tinha também Os dois papas, de Meirelles, e o Democracia em Vertigem, de Pietra Costa, sobre o golpe jurídicoparlamentar contra Dilma Rousseff, que eu havia me recusado a ver, por imaginar demasiado triste. A direção de fotografia era assinada por João Atala, colega de longa data de Júlio Costantini. Recordei brevemente os momentos que estivemos nós três juntos no laboratório de fotografia que sobrevivia no subsolo da UFRJ, no Instituto de Filosofia e Ciências Sociais, no centro do Rio. Naquela época, há quinze anos atrás, o laboratório abandonado era tocado pelos próprios alunos. Aprendi com dois colegas veteranos como usar as químicas e manipular 0 velho ampliador. Entrava na pequena sala de luz vermelha, matava umas três ou quatro baratas cascudas, varria 0 chão, ligava a rádio MEC e passava horas a fio no laboratório fazendo experiências com ampliadores e químicas. Pouco tempo depois, o laboratório foi recuperado e o acesso restrito. Cacei com os olhos o nome de Silvio Tendler pela folha do jornal da 


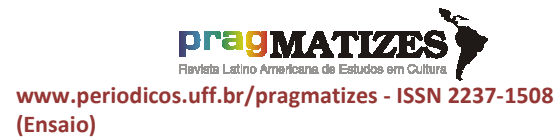

programação. Estava lá! Santiago de las Américas, 2019. Com uma película justamente sobre Santiago Alvarez. "Tenho que assistir", pensei, embora ainda não soubesse quando a fita como dizem os antigos - seria exibida. A casa de Carmen e Ignácio ficava perto da Cinemateca de Cuba e do majestoso Cine Charles Chaplin. Teria então que perseguir no mural diário colado na parede qual seria o dia da exibição do documentário.

Lembro da primeira vez que assisti Jango. Foi uma espécie de sessão especial da aula de geografia, no auditório do quarto andar da escola. Foi a primeira vez que vi as imagens do histórico comício da Central do Brasil, proferido pelo Jango pouco antes do Golpe de 64. Tendler desenvolve em seus documentários uma linguagem de comunicação dinâmica e bem organizada, muito adequada para uso histórico-didático e de formação política. Pouco tempo depois, recordo que assistira no cinema do Museu da República, no Palácio do Catete, toda a sequência histórica de curtas sobre presidentes da república do Brasil. Estava então prestando vestibular, não gostava do estudo formal, no "claustro", e não cogitava nem sombra da ideia de fazer curso preparatório. Preferia ir ao cinema, tocar violão, fazer música, jogar bola, sair com os amigos e amigas pra beber, me apaixonar, me perder na cidade e ler literatura no transporte público. Os documentários do Silvio Tendler eram verdadeiras aulas de história do Brasil.

Tinha visto ainda no cinema o seu documentário sobre Glauber Rocha. Silvio filmara o enterro do Glauber, inclusive o corpo morto. Lembro, como fosse ontem, do discurso emocionante do Darcy Ribeiro, à beira do sepulcro, em close - como eram revoltas e bárbaras as sobrancelhas de Darcy Ribeiro! Ingressava então no bacharelado em Ciências Sociais na antiga Nacional de Filosofia, hoje Federal do Rio de Janeiro, no Largo do São Francisco, na Uruguaiana. Estava no térreo, conversando com uns colegas, em frente à antiga escadaria de madeira. Havia adquirido meu primeiro telefone celular, no final de 2003, com algum tempo de defasagem em relação a outros colegas. Ma usava ainda o aparelho - um Nokia tijolinho cinza. Júlio me telefonou. Leonel Brizola havia acabado de morrer em 


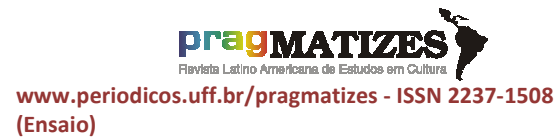

Copacabana. O corpo seria velado no Palácio da Guanabara. Júlio estava então com uma câmera digital emprestada em casa e com umas fitinhas de vídeo pequenas que duravam algumas horas. A paixão de Júlio pelo cinema e pela fotografia vinha desde a infância, superada em tempo somente por semelhante paixão por aviões e aeroportos. Muito antes que qualquer outro colega da minha geração, Júlio já lia e estudava sobre câmera, fotografia, cinema (e aviões) e já produzia curtas de forma independente com poucos colegas. "Vamos agora pra lá filmar. Tem que ser agora!"

Júlio estava então de muletas por conta de uma placa de aço que tivera que colocar no tornozelo de uma das pernas e não podia se deslocar. Eu nunca tinha operado uma câmera. Naquele mesmo ano tinha assistido uma exibição do filme proibido do Glauber Rocha sobre Di Cavalcanti. Glauber filmara o caixão e o corpo do Di. Por conta do constrangimento com a família do pintor o filme foi embargado na justiça. Foi uma sessão inesquecível do Cine Odeon, na Cinelândia, em uma das madrugadas incríveis do Cachaça Cinema Clube, frequentada em peso pelos estudantes do IFCS $^{3}$. Não sei como conseguiram passar aquela fita. Peguei um ônibus na Avenida Passos e fui voando para Laranjeiras. Tínhamos então a pueril ambição de filmar o velório do Brizola, em ousada analogia ao que fizera Glauber com Di e Silvio com Glauber. Não sabia operar uma câmera, não tínhamos equipamento de som e não sabíamos o que filmar. Apenas uma vaga ideia na cabeça e uma emoção difusa. Entramos na fila de populares que se formava. Fazíamos parte da primeira geração posterior à Ditadura Militar. O conhecimento do significado histórico da liderança política de Brizola nos era interditado pela mídia burguesa neoliberal que apoiara francamente a Ditadura Militar e manipulava a opinião pública com o terror midiático dos noticiários de violência urbana. Tínhamos, entretanto, algo em comum: a convicção política debatida no seio familiar, a qual discerníamos ainda sem tanta clareza, pois tal convicção vai decantando com o tempo e não

\footnotetext{
${ }^{3}$ Nota do editor. IFCS é o Instituto de Filosofia e Ciências Sociais da Universidade Federal do Rio de Janeiro, UFRJ.

Aproveitamos para registrar que as imagens sem fonte identificada são todas fotografias do autor do ensaio.
} 


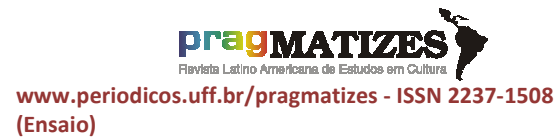

(Ensaio) aparece de forma exatamente transparente aos jovens. Estávamos em franca construção de nossa consciência política. Foi um dia crucial e inesquecível onde consolidamos nossa amizade e paixão pelo cinema.

Filmamos horas do velório, inclusive o corpo morto. Eu estava com medo, mas joguei a câmera sobre - caixão buscando a face difícil através do vidro emoldurado, entre os guardas palacianos com penachos. Não havia muito tempo. Filmamos de todo, personalidades políticas, familiares. Passaram as horas e fomos enfim compreendendo quem era 0 verdadeiro sujeito daquela história. Uma fila imensa dobrava o quarteirão. Leva-se quase três horas na fila para entrar no Palácio da Guanabara e ficar alguns poucos segundos diante do corpo do velho. Essas pessoas eram os verdadeiros personagens. Começamos então a filmar a enorme fila, de cabo a rabo. Ainda não estava popularizado o uso de celulares, nem difundida a naturalidade no lidar com câmeras, fotos ou selfies. Não era fácil sustentar uma câmera próxima das pessoas, muitos se sentiam inibidos, mas com o tempo foi-se construindo uma cumplicidade, como se soubessem o que estávamos fazendo.

Decidimos editar 0 material logo, sem esperar o tempo transformar o valor daquelas imagens. Excluímos todas as imagens de personalidades políticas ou familiares e investimos em um conceito de edição e montagem que se concentrasse apenas na nossa experiência de descoberta dos verdadeiros sujeitos daquela história. Fizemos então o curta-metragem independente Ou ficar a pátria livre (2005), com um emocionante plano sequência de quase quinze minutos da fila. Colocamos algumas músicas que faziam sentido pra nós em cima das imagens. O filme ficou, digamos, ruim. Óbvio. Eram imagens de quem não sabia segurar uma câmera. Imagens de quem estava em pleno processo de descoberta. $O$ fato de ser um filme ruim e amador nunca tirou nossa convicção de que estávamos certos em fazer logo e fizemos, sem qualquer recurso ou apoio. Durante os créditos, colocamos a voz da Beth Carvalho cantando à capela o Hino da Independência que havíamos captado na Candelária, na missa de sétimo dia. Dedicamos 0 documentário aos nossos pais. Júlio assinou como "Júlio 


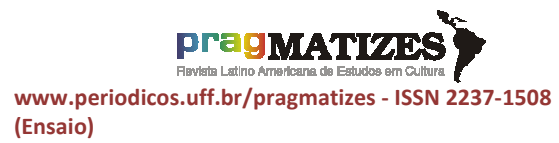

Costantini Jr." - continuou omitindo o segundo nome, "César", mas resolveu deixar o "Júnior", com razão. Poucos anos depois ele se mudaria para San Antonio de los Baños para cursar a EICTV e eu iria fazer minha primeira viagem a Cuba com a intenção de visitá-lo e conhecer a ilha. Foi quando participei pela primeira vez do Festival Internacional de Nuevo Cine Latinoamericano, em dezembro de 2008.

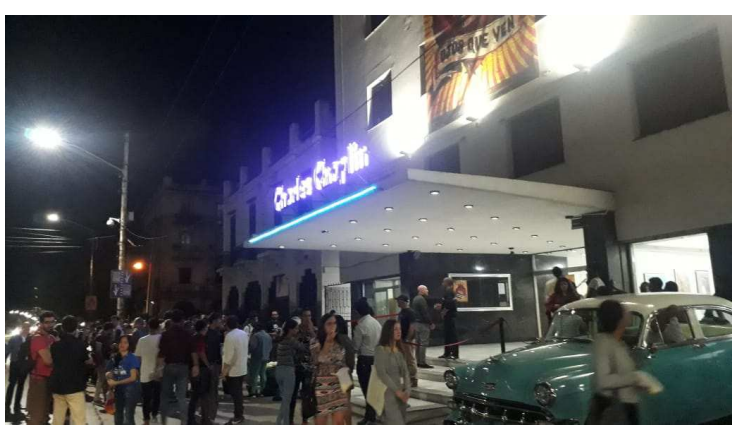

Cine Charles Chaplin, na Av. 23, durante o 41 Festival Internacional de Nuevo Cine Latinoamericano.

"Hola, es de la Fundación Alejo Carpentier? Buenos dias, aqui es Marcelo. Si, si, el brasileño. Hola, Rafael, como estás?" Fui encaminhado por telefone à bibliotecária Margarita. Deveria sugerir então as entradas de pesquisa que ela prepararia para minha consulta. A Fundación Alejo Carpentier é uma ONG sem fins lucrativos. Uma instituição privada que preserva a memória deste que talvez seja o mais importante escritor cubano do século $\mathrm{XX}$. "Si, vamos: primero, me gustaria saber se yo poderia consultar alguna espécie de catálogo de la biblioteca personal de Carpentier". $\mathrm{O}$ portunhol saía com algum esforço."Me interessaria también algunos materiales acerca la relación de Alejo con el antropólogo cubano Fernando Ortiz. Si, si, algunos trabajos acerca de esta relación, se hay alguna cosa en su biblioteca personal". A bibliotecária parecia estar anotando as entradas que sugeria. "Me gustaria también saber se poderia acessar las publicaciones recientes de la Fundación. Yo sé que ustedes publicaran muchas cosas en los últimos diez años...". Queria de fato saber como eu poderia adquirir essas publicações. A bibliotecária me explicou que estavam todas esgotadas e que eles, por serem uma instituição sem fins lucrativos, não comercializavam as edições. Margarita parecia conduzir a conversa para o fim, ao que a interrompi, solicitando mais uma última entrada. "Me gostaria saber se ustedes tienem algun material bibliográfico acerca de la 


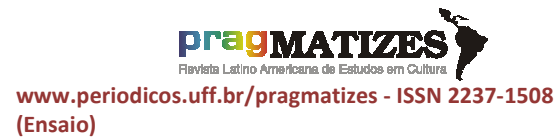

(Ensaio) relación de Carpentier con el pensamiento católico, especialmente con el pensamiento católico francês; alguna cosa acerca de la relación de Carpentier con la Action Française, o con Jacques Maritain, por exemplo, en su estadia en Francia". Diante do relativo espanto e hesitação eu resolvi justificar que tal relação, embora muitas vezes desconfortável para alguns autores, estava aparecendo na obra de outros intelectuais latinoamericanos que iniciaram sua produção nos anos 1920 e 1930. "Muy bién”. Muito simpática, a bibliotecária se despediu então explicando que eu poderia consultar os materiais possíveis logo na semana seguinte, “jueves". Era quinta-feira, então, levaria ainda... lunes, martes, miercoles, jueves... exatamente uma semana para conseguir acessar os materiais separados pela Fundación.

Voltei pra casa pensando que fizera bem em planejar quase vinte dias em Havana para fazer a pesquisa. O tempo é outro em Cuba. Já havia concluído em três dias a novela do Padura, mesmo enrolando pra durar mais, e lembrei que tinha ainda comigo os Poemas, do Maiakovski, e a Harpa e a sombra, de Alejo Carpentier. O interessante da construção da personagem Mario Conde, de Padura, é que ele se envolve demais no caso. Manolo, seu parceiro, chega a criticálo por isso. A dinâmica investigativa evolui no plano exterior e interior da personagem. As descobertas mobilizadas pelo "método Mario Conde" articulam as provas colhidas em diferentes situações com insights intersubjetivos colhidos na experiência, na memória e no ressentimento da própria personagem. A solução do "caso exterior" implica uma solução do seu "caso interior". O perigo de se "envolver demais" no caso, paradoxalmente, é o que leva o detetive de Padura ao êxito, tal qual o veneno leva ao remédio. Em Máscaras, o incrível do caso - um assassinato com motivação homofóbica - é que essa personagem criolla, machista e meio decadente se vê impelida a questionar seus próprios preconceitos e, em alguma medida, seu próprio ideal de honra masculina, para chegar ao autor do crime. Claro, hasta cierto punto, como diria Titón. Mário não sairia do armário, pelo menos ainda, mas a lógica investigativa proposta por Padura compreende o afeto como método. 


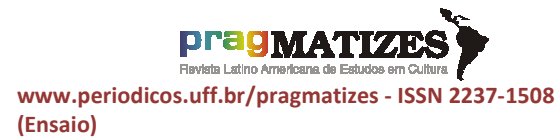
(Ensaio)
Para tanto, seria necessário ao investigador desenvolver certa técnica subjetiva - uma clínica - capaz de relacionar diferentes experiências e provas colhidas no plano exterior com ideias que circulam e se associam, nunca casualmente, a partir do afeto, no plano interior. Mario Conde sistematiza sua experiência e intuição muitas vezes à revelia do próprio controle racional sobre o processo investigativo. A homologia entre o caso exterior e o caso interior pode ser levada no limite do "erro", mas sem nunca abrir mão da prova. Por sua vez, os níveis de análise tipificados como interior e exterior não devem ser compreendidos de forma isolada ou dicotômica. São níveis de análise, separados abstratamente. A realidade se estrutura desde o princípio como uma totalidade dentro-fora, ao mesmo tempo, una e múltipla, geral e particular, operando classificações subjetivas mediadas pelo afeto. Carlo Ginzburg, em Relações de força, observa com razão que os avatares qualitativos e políticos da pesquisa científica não entram em cena apenas ao final, transcorrida a pesquisa e a coleta de material, para enfim imprimir sua marca ou singularidade. Ao contrário, todo 0 processo metodológico de recorte do objeto, levantamento da dimensão empírica, tratamento e escolha de documentos e provas configura-se a partir do afeto e o afeto é, antes de mais nada, político. Tal consideração não descarta ou anula a prova, senão o contrário. $A$ prova é parte necessária da retórica. $\mathrm{O}$ "risco de se envolver demais", tal como sugestionado pelo "método Mario Conde", configura um risco necessário a ser vivenciado por todo aquele ou aquela que se enreda na incessante busca por conhecimento e pretende ir "além-mar".

Boris Schnaiderman observa o incrível tratamento metodológico dado pelos irmãos Augusto e Haroldo Campos na tradução dos poemas de Maiakovski. O princípio filosófico da "tradução literal" é um equívoco que separa forma e conteúdo. O mesmo dizia Jorge Luis Borges. No caso dos poemas de Maiakovski, o paradoxo parece ainda mais gritante. $O$ jovem poeta russo revolucionou a técnica dos versos livres. A partir da experimentação modernista dos recursos gráficos do poema-panfleto, Maiakovski explorou a palavra falada e grafada de formas que mal 
poderíamos supor. Superado o realismo rasteiro do paradigma mecanicista da "tradução literal", o método proposto pelos irmãos Campos enfatiza radicalmente 0 ato de traduzir como recriação poética. $O$ interesse filosófico da vanguarda paulista com Maiakovski pareceu-me evidente. Pode-se apreender um verdadeiro manifesto construtivista não-escrito no corpo do próprio método de tradução empreendido por Augusto e Haroldo. Maiakovski foi um poeta completamente antenado com as inovações técnicas do cinema e da propaganda política na Rússia revolucionária do primeiro pós-guerra. Nada parece-me casual. Tudo é imprescindível. A "história de amor" entre Cuba e Rússia revelava uma significativa gama de relações e contrastes se a arqueologia cultural dessa combinação heterodoxa for empreendida com 0 devido rigor metodológico. Entra-se numa sala de cinema como numa nota de pé de página. Anotei em meu caderno: Boris Schnaiderman cita um artigo de Paulo Emílio sobre a relação entre Maiakovski e o cinema. "Vou perguntar ao Ricardo", pensei. Paulo Emílio Salles Gomes, figura-chave da vanguarda crítica paulista, foi diretor da Cinemateca de Paris no começo dos anos 1960. Depois de finalizado seu doutorado na Alemanha, Ricardo seguia os passos e temas trabalhados pelo Laboratório Cidade e Poder, da UFF, e conduzia em Bremen uma pesquisa de pós-doutorado sobre Paulo Emílio e o cinema.

No dia seguinte, fui na Cinemateca de Cuba assistir o documentário de Silvio Tendler sobre Santiago Alvarez. Compreendi então que a linguagem narrativa documental trabalhada por Silvio tinha tudo a ver com Santiago Alvarez. Mais do que isso: Santiago foi uma espécie de Maiakovski do cinema documental. Reinventando o cinema-panfleto, Santiago desenvolveu diversas inovações gráficas e narrativas na montagem dos seus documentários. Considerado precursor dos videoclipes a partir de seu aclamado Now!, o documentarista cubano empreendeu a "câmera ligeira" em suas produções, inclusive no Noticieiro Cubano, que produzia semanalmente desde sua oficina no ICAIC. Na linha de front do enfrentamento ideológico contra a propaganda política norte-americana, Santiago foi diversas vezes ao 
Vietnam, com sua equipe diminuta, denunciando a invasão norteamericana, o estarrecedor desprezo pelos direitos humanos no uso das armas químicas, mas também apresentando ao mundo a resistência vietnamita. Foi o responsável pela maior quantidade de imagens documentais de Ho-chi-min. A velocidade técnica imposta pela própria dinâmica do campo de batalha transformou a linguagem e a montagem do cinema documental. Tendler observa que os filmes de Santiago Alvarez funcionavam como porta-vozes do "terceiro mundo" nos anos 1960 e 1970, furando o controle e a censura imposta pelo cinturão de ditaduras militares patrocinadas pelos EUA na América Latina.

Voltei para casa pensando em todas essas relações que fervilhavam em minha cabeça. Eu sabia que, em $A$ harpa e a sombra, Alejo Carpentier encenava o leito da morte de Cristóvão Colombo.Trata-se da última ficção do autor, produzida ao fim de sua vida. Carpentier recria em sua última novela os debates em torno da tentativa de beatificação de Colombo, contracenando personagens históricos de tempos distintos. Leon Bloy, influente poeta católico francês do final do século XIX, foi defensor ardoroso da tese de beatificação do "Descobridor" junto ao papa Pio IX, o "papa chileno", como chamado por uns, e depois junto ao papa Leão XIII. Era impensável então a possibilidade de um papa jesuíta, muito menos um papa argentino! Leon Bloy escreveu uma biografia apologética sobre Colombo. Na narrativa de Carpentier, Bloy contracena uma disputa fantástica com Bartolomé de las Casas durante 0 auto-sacramental de Colombo, dentro do Vaticano. Ambas as personagens transcorreram suas vidas em diferentes tempos históricos, mas representavam uma disputa político-ideológica que seguia viva e atual na virada para o século $X X$. Eu intuía que a disputa encenada na última novela de Carpentier representava alegoricamente algumas disputas fundamentais no interior do pensamento católico na passagem à modernidade que faltava ser esclarecida e interpretada.

O papa Leão XIII ensejou a renovação do pensamento tomista na virada para o século $X X$. O jesuitismo foi consolidando sua retomada no final do século XIX, apoiando-se na 


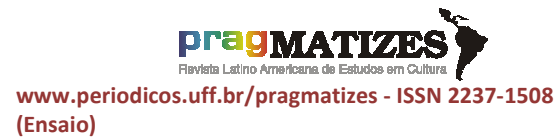

encíclica papal da Rerum Novarum, de 1891. Cabe recordar que os jesuítas foram expulsos do espaço político e cultural ibero-americano em 1756. Trata-se de um contexto históricopolítico marcado pela disputa da soberania no curso do complexo processo de secularização e de submissão da igreja romana ao Estado tanto em Portugal, quanto na Espanha, mas também nas Américas, no curso das guerras de Independência. Leon Bloy foi uma figura pública carismática e sedutora. Foi por influência de Bloy que Jacques Maritain e sua esposa, Raissa Oumansoff, iniciaram as leituras de São Tomás de Aquino e se converteram ao catolicismo, no contexto da Terceira Escolástica.

A Action Française, por sua vez, fundada em 1898, foi um movimento político e filosófico conservador de corte nacionalista que defendeu a restauração monárquica na França (do ramo orleanista) e exerceu influência política na virada para o século $X X$. $O$ movimento foi criado no auge do acirramento político propiciado pelo Caso Dreyfus, que dividiu a sociedade francesa na época. A condenação injusta de Alfred Dreyfus foi denunciada pelo escritor libertário
Émilie Zola em sua famosa carta pública J'accuse!, dirigida ao então presidente Félix Faure. Publicada no jornal L'Aurore, no dia 13 de janeiro de 1898, a carta de Zola desvelou ao mundo a presença do antissemitismo na sociedade francesa. O Caso Dreyfus polarizou a luta de classes na França da Terceira República (18701940) e repercutiu na Europa e América. A Action Fraçaise contribuiu para o desenvolvimento de uma perspectiva cristã conservadora que anos mais tarde desaguaria paradoxalmente no colaboracionismo francês com a ocupação nazista na chamada França de Vichy. Alejo Carpentier relata em seus textos autobiográficos Recuentos de Moradas que o desencanto político propiciado pelo Caso Dreyfus foi um dos motivos que levaram seus pais a deixarem a França no começo do século $X X$ e se estabelecerem em Cuba.

O pai de Alejo Carpentier, Georges Julien Carpentier, foi um arquiteto francês, nascido em 1884, em Marselha. Sua mãe, Ekaterina Blagoobrazova, conhecida posteriormente com o pseudônimo Lina Valmont, foi professora de idiomas e nasceu em 1884, em Nizhni 


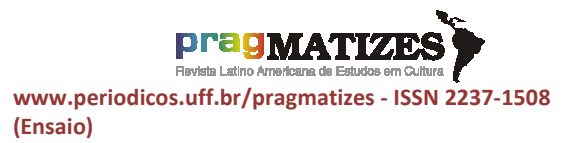

Novgorod, na Rússia. Alexis Carpentier nasceu em 26 de dezembro de 1904, em Lausanna, na Suíça. O autor começou a assinar com o nome Alejo (dentre outros pseudônimos experimentados, inclusive Lina Valmont) em alguns artigos de jornais e revistas, em meados da década de 1920. Não se sabe precisamente quando a família se mudou para La Havana, mas foi entre os anos de 1908 e 1909. Durante muito tempo a questão da origem nacional de Alejo Carpentier foi uma história mal contada; isso porque 0 escritor afirmava ter nascido em Cuba. O escritor fora alfabetizado em francês e espanhol. A língua familiar de Alejo e a troca epistolar com sua mãe se dava tanto em espanhol quanto em francês - sua mãe era chamada pelo escritor carinhosamente de Toutuche - "tudo toca”, em francês. Tão zeloso que era pela sua "cubanidade", o escritor mal conseguia disfarçar 0 sotaque afrancesado. Alejo puxava o "rrr" típico da fala francesa. $O$ sotaque estrangeirado criava certo desconforto. Em uma das cartas à sua mãe, Alejo afirma que se sentia mais à vontade em Paris, onde não vivia a "obsesión de mi acento". 4

José Miguel Wisnik, no artigo $O$ que se pode saber de um homem?, publicado na revista Piauí, em outubro de 2015, refere-se ao impacto produzido pela escuta da voz de Mário de Andrade - "como levar um soco". O registro único e inédito da voz de Mário residia incógnito na Universidade de Indiana, nos EUA, até ser descoberto pelo musicólogo Xavier Vatin, da Universidade do Recôncavo da Bahia. A voz de Mário de Andrade cantando junto com Raquel de Queiroz e Mary Pedrosa algumas cantilenas populares colhidas em suas viagens humboltianas de "turista aprendiz" pelos sertões do Brasil, foi registrada pelo linguista norte-americano Lorenzo Turner e pode ser hoje apreciada com alguns cliques no sítio eletrônico da USP. ${ }^{5}$ Wisnik observa que "diferentemente dos textos e das fotografias, a voz vem de dentro da pessoa, secreta sinais físicos, não verbais, de uma aura, de uma dicção,

\footnotetext{
${ }^{4}$ CARPENTIER, Alejo. Cartas a Toutuche. La Havana: Editorial Letras Cubanas, 2010, p. 46.

${ }^{5}$ Para ouvir a voz de Mário de Andrade basta acessar o endereço eletrônico a seguir: http://www.ieb.usp.br/noticia/mrio-de-andraderaquel-de-queiroz-emary-pedrosa-cantampara-lorenzo-turner.
} 


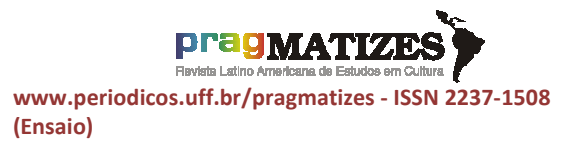
(Ensaio) de uma classe social, de uma época, como se projetasse corpo e alma em holograma, direto do inconsciente pessoal e social." O assombro de Wisnik deve-se à dicção cultivada ao extremo deste poeta que se propunha a trocar o português escrito pelo brasileiro falado como parte do conteúdo programático da sua poesia. Wisnik surpreende-se com as marcas exageradas da dicção da elite paulista, "perolada e castiça, quase catedralesca de tão empinada", deste que se propunha a escrever poesia brasileira numa "língua curumim", "saboreando as palavras num 'remeleixo melado melancólico', na 'fala impura' e coloquial de 'nossa gente', com a boca cheia de 'gostosura quente' do amendoim". 6 No caso de Alejo, 0 sotaque estrangeirado provavelmente dificultava a interação social do escritor com a elite intelectual criolla. Observa-se que as famílias que imigraram no começo do século $X X$ para as Américas foram, em grande maioria, famílias de origem pobre que buscavam trabalho e prosperidade no "Novo Mundo".

\footnotetext{
${ }^{6}$ WISNIK, José Miguel. O que se pode saber de um homem? Revista Piauí, n. 109, Rio de Janeiro (Editora Alvinegra), p. 60-66, outubro de 2015.
}

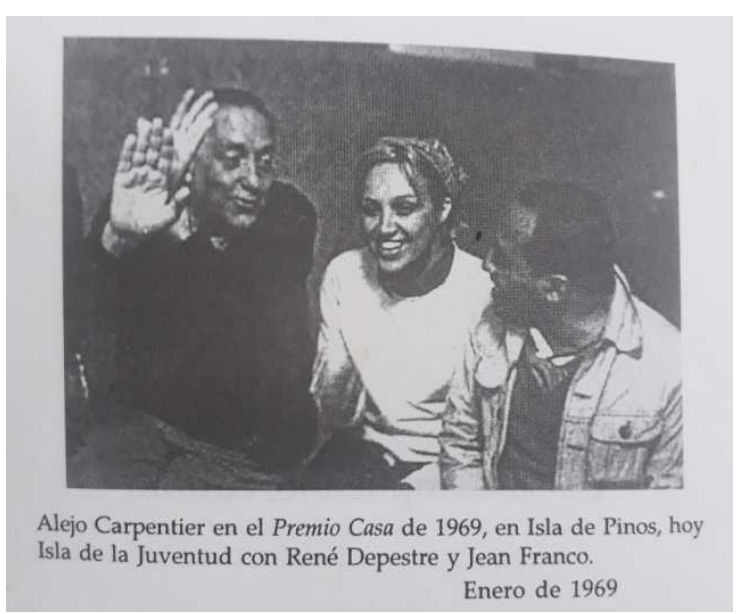

Em julho de 1927, Alejo foi preso político durante 0 recrudescimento do governo autoritário de Gerardo Machado. Diante do risco de extradição por conta de sua origem estrangeira, o escritor se declarou cubano e com apoio decisivo de Emilio Roig de Leuchsenring, então já diretor do periódico Carteles, Alejo conseguiu documentação necessária afirmando que nascera em Cuba. O segredo seria mantido até o fim de sua vida Alejo continuou afirmando ter nascido em Cuba, em diversas entrevistas e depoimentos autobiográficos. No mesmo ano,o jovem escritor partiu em exílio para Paris, onde seguiria atuando como colaborador dos periódicos Carteles e Excelsior, dentre outros jornais da época que tinham considerável circulação em Cuba. Essa primeira estadia de Alejo em 


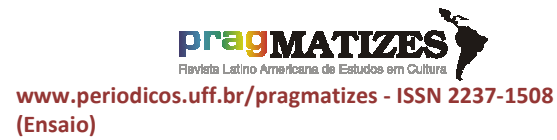

Paris durou pouco mais de uma década. O escritor se estabeleceu no Bairro Latino e participou ativamente da vida cultural parisiense do primeiro pós-guerra. Fluente no espanhol e no francês, Alejo trabalhou como jornalista, crítico, tradutor e mediador cultural das vanguardas intelectuais que circulavam pela cidade. Tal qual outros intelectuais latino-americanos na conjuntura, nota-se que a formação poliglota conferia certa vantagem relativa ao escritor na circulação entre redes intelectuais europeias.

Sustentando a polêmica com a "literatura gauchesca" na Argentina, Jorge Luis Borges observa no célebre ensaio $O$ escritor argentino $e$ a tradição que a ideia de uma "literatura nacional" seria uma moda intelectual europeia importada que deveria ser repelida pelos latino-americanos. O arguto crítico reverte a etiqueta "ideias importadas" contra aqueles que se julgavam guardiões do verdadeiro "nacionalismo literário". Borges, assim como Carpentier, atuou como tradutor e mediador cultural das vanguardas intelectuais modernistas no período entre guerras. $O$ escritor argentino refletiu sobre a vantagem relativa da condição periférica latino-americana em relação ao empobrecimento intelectual guiado pelo fervor nacionalista que vingava de forma crescente em diversos países da Europa. Sérgio Miceli observa em Vanguardas em retrocesso (2012) que ao chegar a Madrid, Borges ficou surpreso ao constatar que os poetas espanhóis de sua geração liam os autores franceses em traduções e jamais no original, pois não dominavam nenhum outro idioma.

Nota-se que a revelação posterior da origem estrangeira de Alejo Carpentier, embora tenha mobilizado certo alvoroço da crítica no que diz respeito à (des)qualificação do caráter autêntico de sua "cubanidade", não configurou-se como um capricho pitoresco desimportante, mas um fato político constitutivo da trajetória intelectual do autor. Não deixa de ser sintomático que Carpentier tenha escolhido justamente o pseudônimo "Alejo". Para além de uma forma de tradução do original "Alexis" para o espanhol, o nome sugere homofonia com a palavra "lejos" - quem vive longe, em distância, em exílio ou desterro. A discussão sobre a origem nacional do escritor foi manipulada no sentido de desconstruir a legitimidade 
de sua condição autoral como monumento da literatura nacional. Por sua vez, observa-se no chiste da ficção biográfica do próprio nome do escritor uma janela para pensar a condição cosmopolita da América Latina e do Caribe, ou do próprio sentido da nacionalidade cubana como identidade una e múltipla, construída no Outro, a partir da transação cultural de múltiplas tradições.

Fazia calor e em Havana não se banha no mar no centro da cidade. Eu estava me preparando para a pesquisa na Fundación, mas ainda faltavam alguns dias. O que será que eles teriam separado para mim? Tomando um ônibus turístico com preços acessíveis perto do Capitólio podia-se conhecer as praias Del Este, frequentadas pelos havaneros aos fins de semana. Ficam em torno de $30 \mathrm{~km}$ do centro de Havana. Eram praias lindas e naturais, apesar dos segmentos turísticos que ocupavam faixas da areia. Um grupo de dez orientais estavam na beira do mar de calça, tênis, bonés, câmeras e não se preocupavam com as ondas $\mathrm{e}$ as roupas. Bastava se afastar um pouco, junto aos coqueiros, e pronto: era como estar na Bahia. Queria ler a
Harpa e a sombra no mar caribenho, embora soubesse que muitas de suas páginas corriam dentro do Vaticano. Daquele dia em diante eu compreenderia o método de viagem que se descortinava: eu construiria uma rotina de leitura e pesquisa, aproveitando o acolhimento da casa de Carmen e Ignácio, alternando com filmes do Festival de Cinema - um por dia, como doses de um rum añejo Santiago - e caminhadas pela cidade, pela sua paisagem de escombros. Tive a intuição que deveria começar a escrever um ensaio "em tempo real" sobre a experiência de campo e sobre todas as ideias que fervilhavam em minha cabeça. Se chamaria "afeto e método em Havana". Sempre ao fim do dia seriam reservadas algumas horas para a escrita e para a compilação dos achados da pesquisa, quase sempre, avançando pela madrugada. Ao fim do dia, voltando para casa, identifiquei um depósito de bebidas perto do Capitólio e comprei duas garrafas de Santiago añejo, meu preferido. Lembrei dos versos que escrevera em dezembro de 2013: 


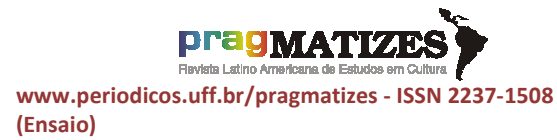

Añejo amor

um ano passou

como três

e ela ficou

tempo veloz

que da espera fez

um fruto sem pressa

que bem madurou

no convés da janela

onde guarda teu canto

o tempo deu vez

ao encontro

instante, tanto, estando

o tempo é um rês

que olha mulheres e homens

como na primeira vez

fumo cobre e cheiro

me leva ao efêmero espanto do óbvio

nos envolve agora um rum vermelho

envelhecido encanto

a fazer da amiga instantânea

um amor añejo

que chega moroso

para um novo ano

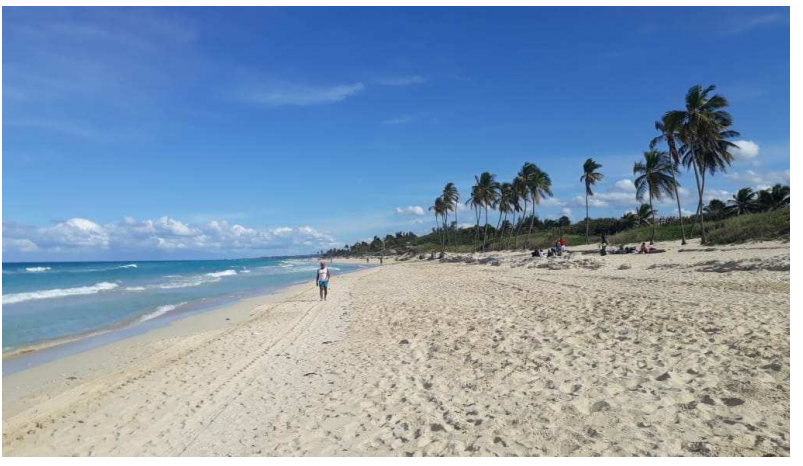

Mar Azul, Praias Del Este, La Havana, Cuba.

Quando cheguei na Fundación me surpreendi com a quantidade de material selecionado pela bibliotecária Margarita. Claro que estava tendo acesso a um material mediado. Alejo tinha em sua biblioteca pessoal diversas obras de Fernando Ortiz. Como imaginado, as mais importantes Los negro brujos e Contrapunteo del tabaco e azúcar, em primeiras edições. São obras fundamentais da antropologia e do pensamento social cubanos que marcam a trajetória de câmbio epistemológico de Ortiz em direção ao culturalismo. Ortiz foi um antropólogo versátil antenado com o que se produzia no mundo, inclusive no Brasil, dado seu interesse pela religião e pela cultura afro-americana. Sua obra sintetiza em uma única trajetória intelectual o que seria uma formidável metamorfose de Nina Rodrigues em Gilberto Freyre. Eu havia pesquisado um pouco de suas principais obras em minha tese de doutorado para compreender o que e como outros intelectuais importantes da geração mais ou menos próxima de Alejo Carpentier, ou um pouco anterior à sua, pensavam a cultura cubana. No caso de Ortiz, um pouco mais velho que Alejo, o câmbio epistemológico é fascinante, pois a mudança da criminologia lombrosiana para o paradigma culturalista parece-me, aos olhos de hoje, uma mudança tão 
radical quanto uma conversão religiosa. Em um curto espaço de tempo, Ortiz conseguiu pegar o bonde da história com as gerações um pouco mais moças e transformar os marcos teórico-metodológicos de seu pensamento - embora mantivesse 0 mesmo interesse original pelas manifestações religiosas afro-cubanas, nomeadas por ele em seus primeiros estudos como fetichismo, tal qual Nina, - famoso médico e sanitarista maranhense, precursor das pesquisas sobre terreiros na Bahia.

Viemos observando na sequência de diversos trabalhos realizados na UFF junto ao Laboratório Cidade e Poder (LCP/UFF) "algo mais" que se manifesta no curso do câmbio epistemológico mobilizado pelas vanguardas latino-americanas nas décadas de 1920 e 1930. A trajetória de Gilberto Freyre é prototípica porque sua guinada para o culturalismo vem acompanhada com sua (nem sempre óbvia) conversão ao catolicismo depois do radical desencanto com sua experiência juvenil estudando em Waco, no Texas, a chamada "Roma protestante" do bible belt do sudeste norte-americano -, no limite mesmo de uma apologia histórica da empresa colonial luso-brasileira. Freyre teve sua formação intelectual no Colégio Batista de Recife e foi preparado para ser um intelectual protestante de destaque, fato que torna sua guinada intelectual ainda mais significativa, tal como pontua Pallares-Burke no livro Um vitoriano nos trópicos. Com o paradigma culturalista, manejando 0 debate sobre identidade nacional, as vanguardas modernistas dos anos 1920 e 1930 se opuseram ao positivismo e ao racismo científico, questionando a visão pejorativa que se tinha da miscigenação, do sincretismo religioso e do próprio conceito de América Latina como uma América "atrasada". Não obstante a palavra "latina" por si só revelasse explicitamente a relação entre iberismo, cultura e catolicismo, a verdade é que muitos pesquisadores engenhosos das gerações mais moças dos anos 1960 e 1970, embebidos pela polarização política na Guerra Fria, pareciam dar pouca importância a tal relação. Os anos de pesquisa junto à UFF e a formação em história social haviam instrumentalizado minha análise para esse "algo mais" - a "questão religiosa" e a força do pensamento católico - que seguia 


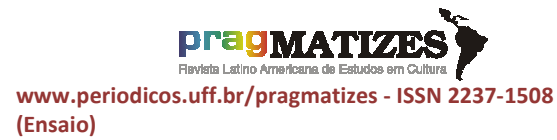

produzindo efeitos decisivos na vida política e cultural no Brasil republicano e na circulação de ideias na América Latina do século $X X$.

Com o câmbio epistemológico, costumeiramente identificado em Contrapunteo del tabaco e azúcar, Fernando Ortiz passou a operar com o conceito de transculturação. No prefácio para a primeira edição do livro, Bronislaw Malinowski define transculturação como:

\begin{abstract}
(...) um processo no qual emerge uma nova realidade, diversa e complexa; uma realidade que não é uma aglomeração mecânica de caracteres, nem um mosaico sequer, e sim uma realidade nova, original $e$ independente. Para descrever tal processo, o vocábulo de raízes latinas transculturação, proporciona um termo que não contém a implicação de que uma determinada cultura tenha de inclinar-se a outra, e sim de uma transição entre duas culturas, ambas ativas, ambas contribuindo com aportes significativos e cooperando para o advento de uma nova realidade de civilização. ${ }^{7}$
\end{abstract}

Em sutil discordância com o conceito anglo-saxão de aculturação que implica certa submissão ou representação passiva de uma determinada cultura dominada frente à outra dominante - 0 conceito de

\footnotetext{
${ }^{7}$ MALINOWSKI, Bronislaw. "Prefácio". In: ORTÍZ, Fernando. Contrapunteo cubano del tabaco y el azúcar. Caracas, Venezuela: Biblioteca Ayacucho, 1987, p. 5.
}

transculturação, "vocábulo de raízes latinas", tal como aponta o célebre antropólogo polonês no referido prefácio, visa dar conta de processos de justaposição cultural enfatizando o caráter ativo de cada cultura relacionada. Tal representação ativa das partes em transação cultural poderia ser identificada mesmo em condições assimétricas de poder, tal como exemplifica, no contexto da dominação colonial, a resistência das práticas culturais e ritos religiosos afroamericanos.

O farol que guia a obra de Ortiz é o mesmo de Alejo Carpentier, que no começo da década de 1930 publica sua primeira obra ficcional, a novela afro-cubana ¡Ecué-Yamba-Ó! (19271933). Muito já foi dito e discutido sobre aproximação de Alejo com o surrealismo, e também sobre como, a partir de certa ruptura com academicismo programático do movimento, o escritor desenvolveu os conceitos de real maravilhoso e de barroco americano para falar dos fascinantes processos de transculturação na América-Latina e Caribe. O próprio escritor narra em seus ensaios, como fragmentos de sua ficção biográfica, tal movimento de 


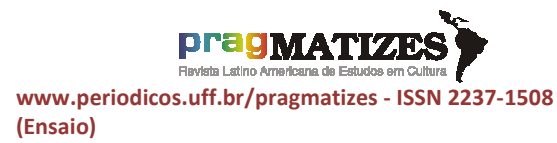

ruptura ou afastamento com 0 "surrealismo acadêmico". Não seria necessário então buscar a origem das suas ideias e ficções em nenhuma cartilha ou "manifesto estrangeiro", pois a própria cultura viva latinoamericana, sua história, suas diásporas e condição ambivalente entre a dependência cultural e a luta por autonomia apresentavam uma riqueza cultural autossuficiente para encaminhar a crítica ao paradigma do liberalismo tradicional e ao iluminismo mecanicista da sociedade industrial uma crítica muito mais eloquente que qualquer manifesto abstrato; uma crítica que poderia ser corporificada na experiência cultural viva e não precisava apoiar-se em "formalidades importadas", nem na obsessão pela influência dos movimentos intelectuais estrangeiros. Esse debate, em certa medida, envelhecido, mas muito importante de ser compreendido em seus argumentos e contexto, faz sentido quando nos situamos em torno dos anos 1960, no curso da Guerra Fria, e no auge do que seria a continuação de um movimento em prol da chamada "literatura nacional". O fato de Malinowski ressaltar as "raízes latinas" do conceito transculturação chama a atenção, uma vez que tal observação filológica não caiu do céu e revela certa sensibilidade para a apreciação crítica da tradição católicoromana que, tanto para intelectuais poloneses, quanto para intelectuais latino-americanos, está na base do nacionalismo cultural. Trata-se de uma "senha" passada por Malinowski. Em Cuba,o nacionalismo cultural ganhou impulso com a Revolução Cubana (1959), tal como sucedeu em outros países no Caribe e na África, no curso da luta anticolonial - embora pareça evidente que o posterior alinhamento político de Cuba com a União Soviética tornou a presença de certos aspectos referidos à cultura religiosa um "passado inconveniente". Compreende-se que a Revolução Cubana de 1959 apresentou-se como realização de uma etapa inconclusa da luta pela Independência de Cuba, franqueada pelo protagonismo intervencionista dos EUA na Guerra Hispano-Americana (1898). Tal sincronia entre o nacionalismo cultural com a Revolução de 59 com certeza conferiu maior durabilidade ao caráter patriótico e nacionalista dos debates intelectuais travados em Cuba. Observa-se que 0 alinhamento 


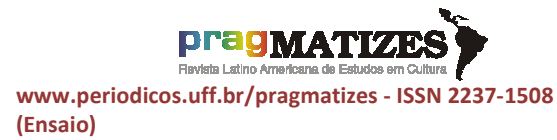

ideológico de Alejo Capentier com a Revolução Cubana apresentou-se como mais um ingrediente que favoreceu a consagração de sua obra como escritor nacional, motivando calorosos debates e disputas políticas que implicaram, inclusive, um feio passado de perseguição cultural e censura a intelectuais que não se enquadrassem no panteão nacional e patriótico alçado pela Revolução. Máscaras, de Leonardo Padura, através do caso absurdo investigado por Mario Conde - um crime de motivação homofóbica, que implica a perseguição política e cultural do próprio sistema oficial - fuxica com maestria tal ferida histórica sem receio de assumir um posicionamento crítico.

Século $\mathrm{XXI}$, as pesquisas em torno da obra de Alejo parecem seguir as mesmas questões, envoltas de mistério e estranhas armadilhas deixadas pelo autor ao longo do caminho. As pesquisas mais avançadas recuperam os anos iniciais de sua formação e produção intelectual e puxam a relação com Ortiz, mas seguem recalcando o fio da história intelectual que conecta 0 conceito de transculturação, assim como de barroco americano, ou de real maravilhoso com suas "raízes latinas", a entender: a afluência do misticismo católico, tomista, inscrito na Terceira Escolástica e no jesuitismo que pulsa como retorno do reprimido e força latente por trás das vanguardas modernistas. O curioso desse fio da história, que deve ser puxado, é que suas raízes não aparecem aos intelectuais latino-americanos de então como "estrangeiras", mas profundamente íntimas da própria cultura dita "nacional" ou "popular". Não obstante o interesse de Alejo e de outros intelectuais de sua geração pela cultura popular afro-americana, especialmente pela religião - mas também pela música popular que tanto fascinava a moda europeia primitivista, como uma forma, digamos, mais secularizada de acessar aqueles estados ritualísticos de transe espiritual em alguma boite parisiense me parecia demasiado curioso que tais interesses não despertassem sentimentos religiosos e análogos deleites com as práticas ritualísticas da cultura católica. Despertavam, claro, como sucede na admiração e afeto pela música de Bach, por exemplo. A questão, de fato, não era se estes elementos apareciam ou não na obra 
do escritor, mas o método ou a chave de leitura necessária para fazer as perguntas certas.

Sobre a mesa, uma grande quantidade de material bibliográfico. Ensaios, crônicas, entrevistas, edições críticas, comentadores, publicações de revistas, uma publicação com a troca epistolar entre Ortiz e Alejo, muitas publicações e edições comemorativas em torno do centenário do escritor, datado em 2004; edições promovidas pela Fundación, outras pela Biblioteca Nacional José Martí, mas não havia propriamente nenhuma publicação ou pesquisa que empreendesse 0 cruzamento analítico do mais importante escritor cubano do século XX com o pensamento católico. A bibliotecária perguntou-me se eu aceitava um café. Disse que sim, para ser educado - ela já estava com o café nas mãos - embora soubesse que estaria decididamente temperado com muito açúcar. Achei que era um bom momento para insistir se ela não havia achado nada sobre a relação de Alejo com o pensamento católico ou se eu poderia acessar o catálogo da biblioteca pessoal do escritor. Margarita disse-me que não havia achado nada especificamente sobre essa relação e que então seria o caso de conversar mais demoradamente com o professor Rafael, na sala ao lado. "Sin problemas", respondi. Continuei a leitura e enrolei um tabaco que já repousava ansioso na mesa, aguardando seu esperado contraponto ao café, na varanda ao lado. Vislumbrava ainda que poderia achar em algumas crônicas de jornal e periódicos, escritas por Alejo nas décadas de 1920 e 1930, alguma coisa de interesse. Intuía que poderia encontrar pelas margens ou periferia de seus textos alguma referência indireta à renovação tomista que, como um fantasma, incidia no pensamento modernista latinoamericano. Eu poderia fazer perguntas aos índices onomásticos das coleções, procurando por referências a São Tomás de Aquino ou Jacques Maritain, por exemplo. Começaram a aparecer os indícios.

Duas crônicas chamaram-me atenção: El encanto cosmopolita del Bairro Latino e El bairro de San Sulpicio - ambas escritas em correspondência para 0 periódico cubano Carteles, em 1929. Neste ano, Alejo Carpentier estava no primeiro ano de sua primeira estadia duradoura 


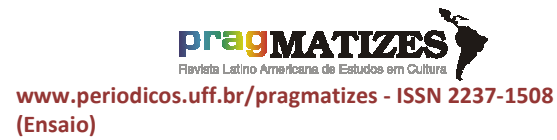

na Europa. O escritor radicou-se em Paris entre 1928 e 1939 - ano que marca o término da Guerra Civil Espanhola (1936-1939) e o início da Segunda Guerra Mundial (1939-1944). A revista Carteles (1919-1960), editada em La Havana, teve grande circulação no público cubano e caribenho, entre as décadas de 1920 e 1940, especialmente a partir de 1924, destacando-se pela qualidade do material ilustrativo e pelo editorial modernizante que encontrara aderência na cultura burguesa dos principais centros urbanos. Alejo Carpetier chegara a ocupar o cargo de editor chefe da Carteles entre 1924 e 1928. Nos idos de 1929, recémchegado a Paris, em exílio, o escritor contribuía como correspondente internacional do periódico, assinando a coluna Desde Paris - que manteve por duas décadas, até 1948. A coletânea de crônicas de periódicos dessa primeira estadia do escritor na Europa fora publicada em dois volumes pelo Editorial Letras Cubanas, em 1985 era precisamente a edição que eu tinha sobre a mesa da Fundación. Ambas as crônicas destacadas relatam aspectos pitorescos da vida cultural, política e urbana da capital francesa e expressam curiosamente o "olhar estrangeiro" do escritor latinoamericano recém-chegado na cidade.

Em El encanto cosmopolita del Bairro Latino, publicado no referido periódico Carteles, em 30 de junho de $1929,{ }^{8}$ Alejo Carpentier narra a agitação cosmopolita de um bairro tomado por restaurantes, bares noturnos, livrarias e estudantes de diversas partes do mundo. O escritor manipula em sua narrativa o contraste entre o caráter cosmopolita e moderno do bairro com as ruínas eclesiásticas do passado medieval. A mistura fantástica de sabores, modas intelectuais e nacionalidades desterradas em agitação política se expressa como vivência erótica do frenesi ruidoso das ruas em contraste com a seriedade silente dos velhos muros eclesiásticos por onde andavam Tomás de Aquino e estudantes de outrora.

Una aglomeración de hombres jovenes procedentes de todos los extremos del planeta, tenía forzosamente que dar un peculiaríssimo aspecto a las calles del Bairro Latino. Ninguna imaginación seria capaz de inventar contrastes tan singulares como los establecidos entre las cosas y las

${ }^{8}$ CARPENTIER, Alejo. "El encanto cosmopolita del Bairro Latino". In: Crónicas. La Havana: Editorial Letras Cubanas, 1985, p. 380-384. 


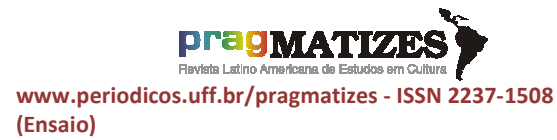
(Ensaio) gentes de este famoso sector de París... Para comenzar, no debe olvidarse que sureplazamiento es simbólico. La Calle de las Escuelas es dominada por laviejísima torre del Convento de Santa Genoveva, donde moraron algunos de los más insgnes teólogos de la Edad Media. Santo Tomás de Aquino, el mayor de todos, paseó muchas veces junto a un viejo muro cubierto de yedra, que se alza todavia en una calleja angosta cercana del Panteón. Más tarde, los clérigos y escolares inquietaron con sus risas y reyertas los alrededores de la iglesia conventual, em una de cuyas naves si situo un dia la tumba del jansenista Pascal.

Hoy, en estas calles que guardán, como pocas, el carácter del Viejo París, hanfijado asiento los establecimientos más arbitrários, traídos por los gustos y costumbres de estudiantes extranjeros. En el espacio compreendido entre la iglesia de Santa Genoveva y el Sena, hallarías actualmente restaurantes y tendas que os permitirían saborear todas las gulosinas de la tierra. ${ }^{9}$

$\mathrm{Na}$ imagem sugerida pelo cronista:um muro coberto de eras, por onde passeava São Tomás de Aquino - "o maior de todos" -, como se este seguisse passeando por aquele mesmo muro que narrador divisava na Paris entre guerras. Por sua vez, em uma das naves da igreja conventual de Santa Genoveva,o cronista marca a presença da tumba do "jansenista Pascal". A escolha desses monumentos, erigidos em torno das

\footnotetext{
${ }^{9}$ Idem, p. 381-382.
}

personas de Tomás de Aquino e Pascal, não é casual. Representa o conflito entre 0 tomismo e o jansenismo no interior do pensamento católico. Como se "gravado" nos muros e construções dos templos medievais, tal conflito é mencionado por Alejo Carpentier com naturalidade, como um debate atual e evidente à mentalidade da época. O narrador, todavia, pretende ressaltar os aspectos "novidadeiros" da cultura e da política parisiense. Com riqueza de detalhes e certo humor típicos de uma narrativa pitoresca - visando comunicar uma experiência incrível ou maravilhosa para seu público leitor -, Carpentier narra muitos sabores, cores e perfumes, sejam de comidas e costumes de diferentes lugares do mundo, sejam de livrarias, modas intelectuais ou de bares noturnos.

No trecho destacado a seguir, nota-se ainda a curiosidade por certo clichê parisiense de sutil fetiche masculino e acento misógino: o caráter surpreendente da liberdade sexual das mulheres e da vida amorosa vivenciada publicamente nas ruas. Tal aspecto da narrativa, embora pareça secundário para o leitor de hoje em dia, mobilizava $o$ interesse $e$ a 
curiosidade dos leitores das revistas mais modernas da época, projetando anseios por maior liberdade individual. Chama atenção ainda 0 destaque dado pelo autor ao "fervor nacional" que agitava então os debates políticos e intelectuais, influindo de sobremaneira nas vanguardas modernistas dos anos 1920 e 1930.

He aqui un grupo de estudiantes ultralatinos, con sus pipas aparatosas y barbitas talladas enpunta; he aqui a los absurdos realistas franceses - adictos al Duque de Guisa, la religión y Charles Maurras - llevando sus boinas de terciopelo y bastones claros. Hay embajadores de Oxford, que lucen knickbockers y corbatas rojas; hay russas y nórdicas, de viva mirada y andar varonil. Se veninditos de nuestra América, que se hacen acompañar por las mujeres más rúbias de todo el bairro; se ven doctores egípcios, futuros leaders autonomistas, que exhibien el perfil inmutable que podríamos hallar en las pinturas milenárias que llevanla Sala Champolion del Museo del Louvre... Se cuentan relativamente pocos estudiantes norteamericanos en las universidades francesas. En cambio, la cifra de famílias asiáticas pudientes que envián sus hijos a estudiaren Lutecia es cada vez mayor. Los estudiantes chinos del bairro latino constituyen, por si solo, una verdadera colonia. Los indochinos son tan numerosos que han comenzado a hacer política nacionalista y antieuropea en Paris, celebrando mettings tan turbulentos que la policía se há visto obligada a llamarlos al orden... En los alrededores de la Sorbona podrías ver cien turbantes hindúes, y hasta las túnicas de seda parda de bachilleres afganos. Encuanto a los turcos, huelga decir que la politica antitradicionalista de Kemal Pachá há propiciado grandemente su nuevo anhelo de recibir una cultura occidental.

Entre todos los estudiantes extranjeros del Bairro Latino, son los latino-americanos quienes penetran más hondamente en la vida parisiense. Tienen numerosos clubs e instituciones. Son mirados con simpatia por el estudiante francês. Suelen destacarse brillantemente en alguna rama del saber, a punto de alternar con las eminencias. Además, todo el mundo sabe que, contrariamente a lo que acontece con los estudiantes de países pobrísimos del centro de Europa, no constituyen una amenazani una competencia para el nativo. El latinoamericano es mantenido por su país, y acaba casi siempre a regressar a él. Es, de todos los metecos, el único aceptado cordialmente por la xenofobia gala. ${ }^{10}$

Alejo pontua os motivos que conferiam aceitação ao latinoamericano - de todos os metecos, o mais aceitado cordialmente pela "xenofobia gala". Estes não representavam, pois, uma ameaça aos nativos: na sua quase totalidade eram estudantes financiados pelos seus países de origem, de formação esmerada e bem qualificados. A grande maioria acabava regressando ao país natal. Em um ambiente cultural e político cada vez mais aquecido pelo fanatismo nacionalista, tal aceitação social favorecia certo trânsito fluente de intelectuais latino-americanos nos

\footnotetext{
${ }^{10}$ Idem, p. 380-381.
} 


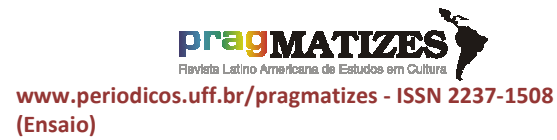
(Ensaio) círculos culturais parisienses. Chama a atenção do cronista o ambiente de liberdade sexual, tal como observado anteriormente. O narrador observa com certo estranhamento (e sutil preconceito) que se veem "inditos de nuestra América” acompanhados das mulheres "mais loiras" de todo o bairro. Algo que seria mesmo impensável nas sociedades miscigenadas, porém, altamente estratificadas, da América Latina. O que seria impensável, aqui, é - caráter público ou civil de tal exercício de liberdade amorosa e não propriamente a relação em si. Sob risco de cair em anacronismo, tal aspecto não deveria ser compreendido com as etiquetas de "machismo" ou "racismo". Nota-se que tal "descalabro" parisiense motivava na época a imaginação e a curiosidade do público leitor em favor de mais liberdade e igualitarismo. Com o avançar do fanatismo nacionalista, tal ambiente de liberdade cultural narrado pelo escritor se esvaneceria no contexto da Guerra Mundial. Com ascensão política do nazismo e o colaboracionismo fascista em toda Europa, com a "derrota da inteligência" na Guerra Civil-Espanhola e a ascensão do franquismo nos meios culturais hispano-americanos, Alejo, assim como muitos outros de sua geração, vivenciaria profundo desencanto com a Europa. A utopia da cultura latino-americana ensejada pela sua literatura, assim como de outros intelectuais de sua geração, deve ser compreendida vis-à-vis o "ocaso da Europa" e a ascensão do fascismo.

No artigo El bairro de San Sulpicio, publicado no periódico Carteles, em 25 agosto de 1929, ${ }^{11}$ o jovem Alejo Carpentier continua variando sobre os contrastes que desenham a cartografia urbana da capital francesa. "Solo Paris es capaz de presentar barrios como el de San Sulpicio, al lado de Montparnasse y del Barrio Latino. Que prodigiosa ley de contrastes habrá regido en la formación de esta ciudad?"12 $\mathrm{O}$ escritor caracteriza o bairro como uma "colônia romana"; por excelência, um "feudo de la gente eclesiástica", cravado entre os dois bairros "más hereges" da cidade.

La iglesia de San Sulpicio pertenece a la série de templos fríos y protocolarios que se alzaron en Francia por años del "gran siglo". Su fachada muestra severos entablamentos clásicos. Sus torres, ajenas a toda la tradición gótica, ostentam columnas que podrían

\footnotetext{
${ }^{11}$ CARPENTIER, Alejo. "El bairro de San Sulpicio". In: Crónicas. La Havana: Editorial Letras Cubanas, 1985, p. 399-403.

${ }^{12}$ Idem, p. 403.
} 


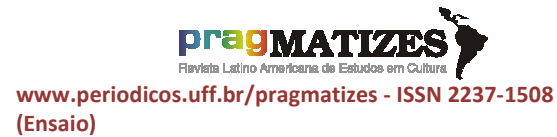

fuerzas recobradas por la religión después de la guerra. ${ }^{3}$

Os "templos frios e protocolares" que se alçaram na França do "grande século" - Alejo se refere ao século XVII. A narrativa desenvolve o contraste cultural do estilo neoclássico de colunas monumentais de inspiração grecoromanas - como um "tratado gráfico de Vignola" - em contraposição com o sentimento de recolhimento, "intimidade" e "calor religioso" dos antigos santuários medievais. Imbuído do espírito cartesiano, o "grande século" Francês foi marcado pelo racionalismo e pelo desenvolvimento do pensamento matemático. Alejo Carpentier estudara arquitetura na Universidad de La Havana. Embora não tenha concluído o curso, suas obras e ensaios promovem franco diálogo filosófico e cultural com a arquitetura, através da interpretação de monumentos, construções e cidades -como falamos anteriormente, seu pai fora também arquiteto.

A igreja de São Sulpício, monumento do "grande século" francês, iniciou sua construção em

\footnotetext{
${ }^{13}$ Idem, p. 339-340.
} 
1646, sobre as ruínas de um templo românico do século XIII. Sua construção durou quase um século. $A$ Igreja se destaca por um sistema de iluminação construído com cálculos astronômicos - tal como os sofisticados templos pré-colombianos das civilizações Inca, Maia e Asteca -, com um esquadro de meridiana para calcular com a luz a chegada da Páscoa. O cronista observa que a experiência diante de São Sulpício permite compreender o espírito de uma época que produziu as "imperturbáveis arquiteturas verbais de Racine". Não seria igualmente casual a menção do célebre dramaturgo que, órfão aos três anos de idade, dirigido pelos cuidados de uma tia e uma avó, teve formação jansenista em PortRoyal, que em meados do século XVII se transformou em um dos principais centros institucionais promotores do jansenismo. Racine continuou seus estudos no Collège de Beauvais e estudou filosofia no Collège d'Harcourt - ambas instituições impregnadas com o "espírito da Port-Royal". ${ }^{14}$ O

\footnotetext{
${ }^{14}$ Maria do Carmo, professora da universidade Federal de Uberlândia, observa a influência do jansenismo e das doutrinas agostinianas de predestinação nas tragédias escritas por Racine. CARMO, Maria Suzana Moreira do. "Fedra", de Jean Racine: moral do século XVII
}

dramaturgo, todavia, se afasta da direção mais rigorosa de sua formação e investe na carreira de escritor para conseguir dinheiro. Observa-se que a tumba de Jean Racine também se encontra em uma das naves da igreja conventual de Santa Genoveva, referida anteriormente, ao lado de Blaise Pascal.

Para o jovem cronista Alejo Carpentier, o templo de São Sulpício é o eixo do maior centro de atividades religiosas de Paris. Sequer a catedral de Notre Dame irradia sombra do poderio católico que se desprende do átrio de São Sulpício. Todas as ruas que rodeiam 0 templo parecem "tributárias de sua autoridade", e todos os comércios e instituições parecem de alguma forma viver para explorar o culto religioso. Numa rua próxima, se encontra a Universidade Católica onde se escutaria conferências dos doutores cristãos mais esclarecidos da época. Ali se poderia ouvir dissertar Jacques Maritain, sobre Santo Tomás de Aquino e sua doutrina - "génesis de uma filosofia que sustenta gran parte de la juventude francesa

e criação literária. Letras, Santa Maria, v. 24, n. 49, p. 153-174, jul./dez. 2014. file:///C:/Users/marce/Downloads/1659774634-1-SM.pdf 


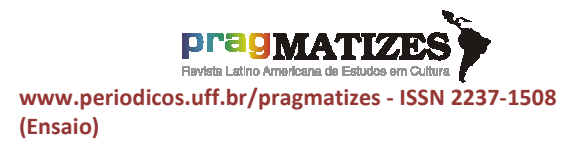
(Ensaio) contemporânea". Alejo se refere ao que chamamos anteriormente de Terceira Escolástica, o movimento intelectual tomista realizado do seio do pensamento católico.

A trajetória de Jacques Maritan (1882-1973), assim como de outros intelectuais daquela conjuntura histórica, é marcada por reviravoltas, transitando entre campos políticos divergentes. Maritain nasceu em Paris em um ambiente familiar e citadino predominado pelo racionalismo liberal. Não foi batizado pelos seus pais e teve uma formação simpática ao protestantismo. Sua trajetória contempla um movimento de guinada do campo positivista e racionalista para o campo místico católico. Estudou filosofia na Sorbonne, em Paris, onde teve aula com Emilie Durkheim. Posteriormente, fez seminários de filosofia com Henri Bergson, já então em companhia de Raissa Oumansoff, imigrante russa de origem judia, com quem se casou no matrimônio civil em 1904. A partir das leituras e da amizade com Leon Le Bloy, o casal converteu-se para o catolicismo, promovendo uma ruptura com sua formação anterior, migrando para o campo tomista. Leon Le Bloy foi padrinho do batismo do casal $\mathrm{e}$ introduziu Jacques Maritain nas leituras de São Tomás de Aquino. O afastamento de Jacques Maritain da perspectiva conservadora da Action Française pode ser entendido à luz da presença do antissemitismo e do "casamento misto" com Raissa que freou a possibilidade de comunhão do jovem casal em torno do ideal ultranacionalista francês.

Em setembro de 1926, o Vaticano condenou a Action Française e seus líderes intelectuais por sua perspectiva cristã que submetia a autoridade soberana católica (romana) ao absolutismo monárquico do Estado francês. Diversos intelectuais que foram apoiadores do movimento dentre eles, o próprio Jacques Maritain - haviam se tornado severos críticos do movimento. Posteriormente, em exílio, durante a ocupação nazista, Jacques Maritain fez oposição ao Regime de Vichy. Com o fim da Segunda Guerra Mundial, o mais influente intelectual tomista francês foi membro participante da composição da Declaração Universal dos Direitos Humanos, realizada pelas Nações Unidas (ONU). Em suas crônicas de jornal, embora não dedique um artigo 
em especial a Maritain, Alejo faz algumas referências à sua atuação intelectual como hábil orador e agitador político católico.

Passei a manhã e o começo da tarde revirando livros e fotografando os materiais separados. No fim do dia, Rafael veio conversar comigo mais demoradamente. "Alejo não era religioso. Sua mulher sim, foi católica, mas ele não. Ao fim da vida eles se casaram na Igreja, por um desejo dela". "Ah, sim, compreendo, se casaram na Igreja?", respondi espantado. "Sim, sim, mas ele não era religioso. Inclusive aquele crucifixo no corredor era da família de sua esposa. Veja, meu pai era maçom, mas por um desejo de minha mãe eles também se casaram na Igreja. E assim se sucedeu com muitas famílias cubanas." "E Carpentier, foi maçom?", perguntei sem hesitar. "Não", respondeu. Eu sabia que os embates entre a franco-maçonaria e a Igreja Católica faziam parte de muitos romances de Alejo Carpentier sobre o processo revolucionário caribenho, tal como aparece em O século das Luzes. Contei que Sérgio Buarque de Holanda também não era propriamente religioso, mas sua esposa, Maria Amélia, sim. Há uma passagem curiosa da ficção autobiográfica $O$ irmão alemão, de Chico Buarque, em que o narrador rememora a biblioteca do pai e sua perplexidade juvenil diante da coleção completa dos sermões de Antônio Vieira. O narrador não compreendia como seu pai tinha tanto interesse pela religião e ao mesmo tempo "detestava a Igreja". "Ah, claro, Alejo tinha sim muito interesse pela religião, mas não como praticante. Foi um profundo conhecedor da Bíblia, inclusive possuía diversas edições da mesma em sua biblioteca. Bom, na novela Concerto Barroco, todas as citações de pé de página são da Bíblia... E todos conhecem a novela $A$ harpa $e$ a Sombra que revive debates políticos no interior do Vaticano. Mas não, nunca foi religioso". Preferi não insistir mais. 

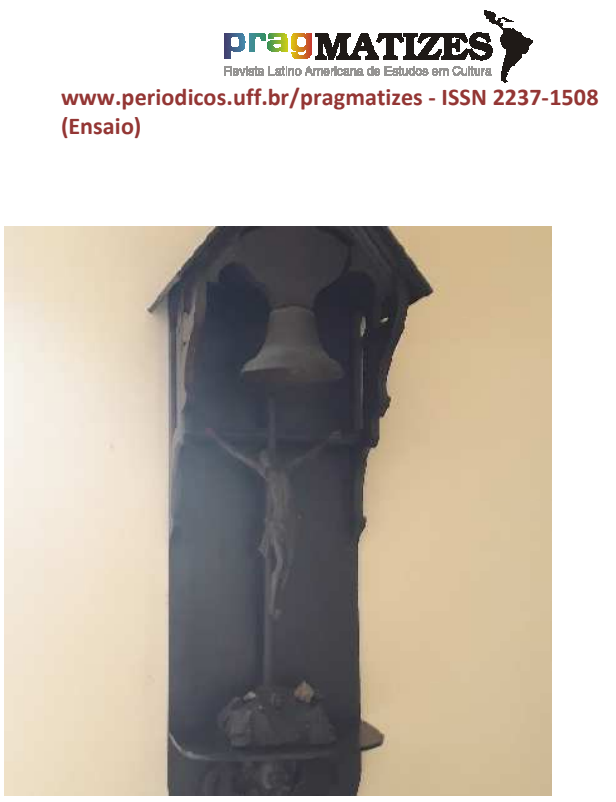

Naquela noite eu iria à Cinemateca de Cuba assistir um documentário sobre o maestro, compositor e violonista cubano Leo Brouwer. Lembro de uma entrevista de Egberto Gismonti publicada no jornal Gramna, em 2008. Foi na primeira vez que estive em Cuba. Comprei por acaso o jornal e me surpreendi com a entrevista. Egberto falava sobre a importância de Brouwer para a música brasileira e para o mundo. O destaque dado ao artista brasileiro trazia um reconhecimento e admiração não muito costumeiro em nossos próprios jornais. Durante anos guardei aquela entrevista recortada em papel de tinta rosa. Adquirira então 0 fascinante álbum duplo Homoludens, de Brouwer. Sabia que a pesquisa estética de Brouwer guardava conexões ainda não exploradas por mim com os conceitos 
manejados por Carpentier e Ortiz. Esperava encontrá-las no documentário, evidente, mas não esperava que o próprio compositor estaria assistindo a sessão.

Antes da exibição do filme, Brouwer falou algumas poucas palavras sobre sua dificuldade com as palavras. Não era sua matéria; como músico, se definia como "artesão dos sons". Foi uma encenação simpática, com lugares comuns e certa "falsa modesta". De fato, o maestro cubano apresentava clareza e rigor em sua concepção estética. O documentário acompanhava momentos de sua intimidade, apresentando de forma poética sua visão sobre a cultura e música em Cuba. Ao mesmo tempo, não consegui esconder de mim mesmo certo desencanto. Brouwer encenava o desgastado papel do célebre maestro exilado em seu próprio país, sem 0 devido reconhecimento nacional, quase esquecido. O documentário trazia cenas de sutil melancolia e beleza, como um mergulho sentimental na estética da decadência criolla em seu "estilo tardio". Brouwer olha para o alto, na sala de sua casa, nostálgico, e clama por seus interlocutores perdidos: "Alejo, Amadeo Roldán, donde están ustedes?" Chamou-me atenção sua observação crítica sobre a festa e a dança. A cultura cubana vivencia alguns dilemas parecidos com - Brasil no que tange à música. O império da alegria e da festa: tudo há que ser festivo e ligeiro, alegre e expansivo. Leo Brouwer questiona tal imperativo. Sua música realiza uma fantástica pesquisa musical sobre um lugar primordial de transe ritualístico e de escuta introspectiva. Desloca o lugar da festa como sinônimo do baile moderno, urbano, sexual e comercial para esse lugar quase atemporal de meditação religiosa e ritualística da cultura afro-cubana. Brouwer dá forma àquilo que poderíamos chamar de "Cuba profunda", produzindo sínteses estéticas de seus processos de transculturação. O compositor, todavia, não recorre de forma simplória ao "folclore" ou às manifestações da cultura popular. O estilo tardio de Brouwer é radical, selvagem e agressivo.

O debate parece-me fundamental. Em dado momento do filme, Brouwer manifesta suas desilusões com os rumos tomados pela música popular cubana comercial, 


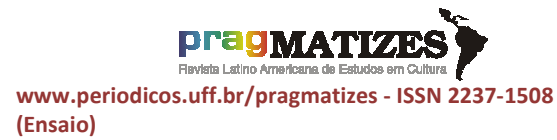

especialmente com o reggaeaton. Ao fim do filme, sobrava ainda um sabor levemente amargo: o sentimento de distanciamento ou incomunicabilidade da culta e erudita "cultura popular" ensejada por Brouwer com seu "próprio povo". Que fazer? Como fugir desse labirinto? Voltei para casa pensando no radical exemplo que a música de Hermeto Pascoal dava ainda hoje, do Jabur, para o mundo. Eram dez horas da noite quando cheguei em casa. Peguei o violão e iniciei uma música nova que me acompanharia até o fim da viagem. Uma canção com ares de bolero que depois passei a chamar de Fresa Bombom, em referência indireta ao Titón.

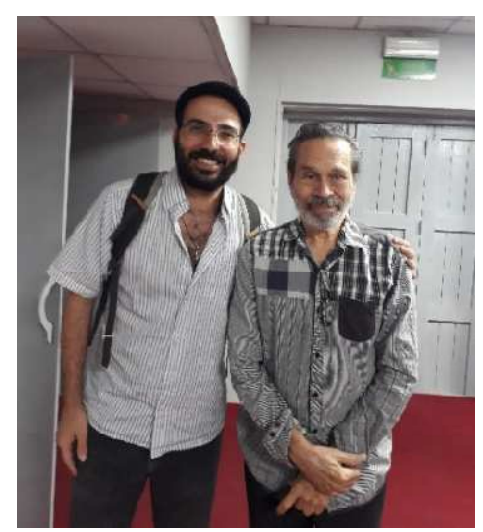

Marcelo Neder e Leo Brouwer, na antessala da Cinemateca de Cuba, em La Havana, dezembro de 2019, após a sessão do documentário Brouwer, elorigen de la sombra, de Katherine $\mathrm{T}$. Gvilán e Lisandra Lopez Fabé (Cuba, 2019).
- Lista de filmes assistidos no 41 Festival Internacional de Nuevo Cine Latinoamericano (um por dia, conforme o método añejo Santiago empreendido durante o período do Festival de Cinema, dos dias 05 ao 15 de dezembro de 2019):

1. La Llorona - Jairo Bustamante (Guatemala, França 2019)

2. La Odissea de losGiles Sebastián Borensztein (Argentina, Espanha, 2019)

3. Santiago das Américas ou o olho do Terceiro Mundo - Silvio Tendler (Brasil, Cuba, 2019)

4. Brouwer, elorigen de la sombra Katherine T. Gvilán e Lisandra Lopez Fabé (Cuba, 2019)

5. Três Verões - PatriciaKogout (Brasil, França 2019)

6. La Cordillera de losSueños Patricio Guzmán (França, Chile, 2019)

7. Bacurau - Kleber Mendonça Filho e Juliano Dornelles (Brasil, França 2019)

8. El Cuento de las Comadrejas Juan Jose Campanella (Argentina, Espanha, 2019)

9. Agosto - Armando Capó Ramos (Cuba, Costa Rica, França, 2019)

10. Marighella - Wagner Moura (Brasil, 2019) 
Acoustic Guitar

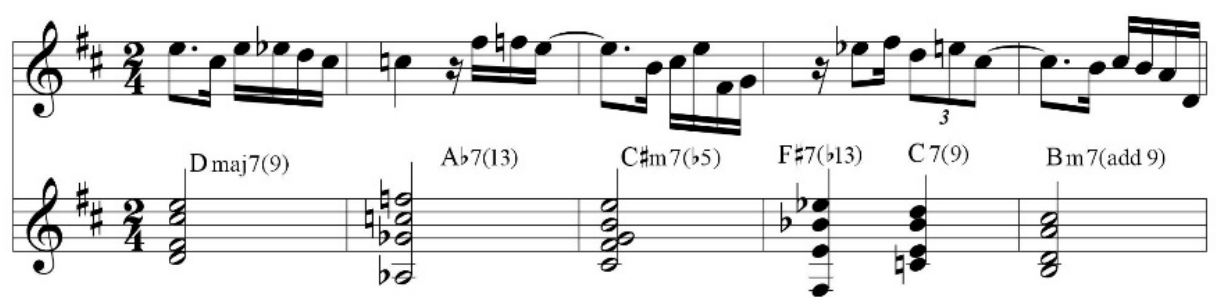

Ac.Gtr.

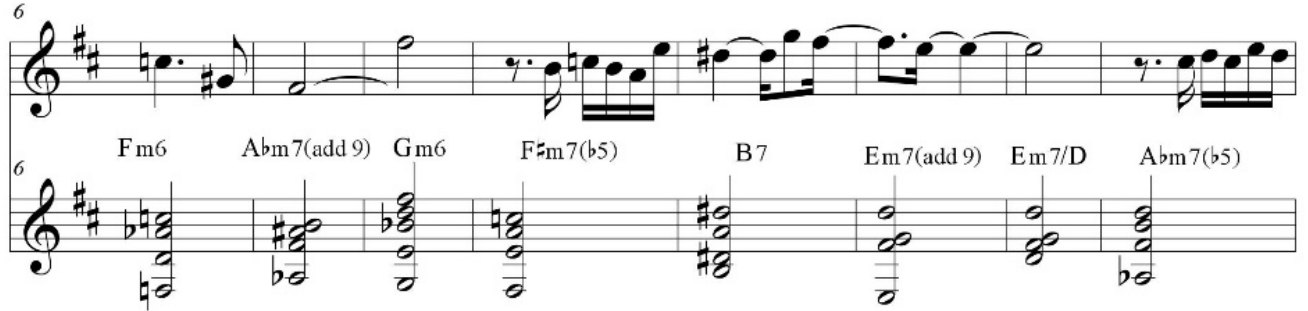

F1.

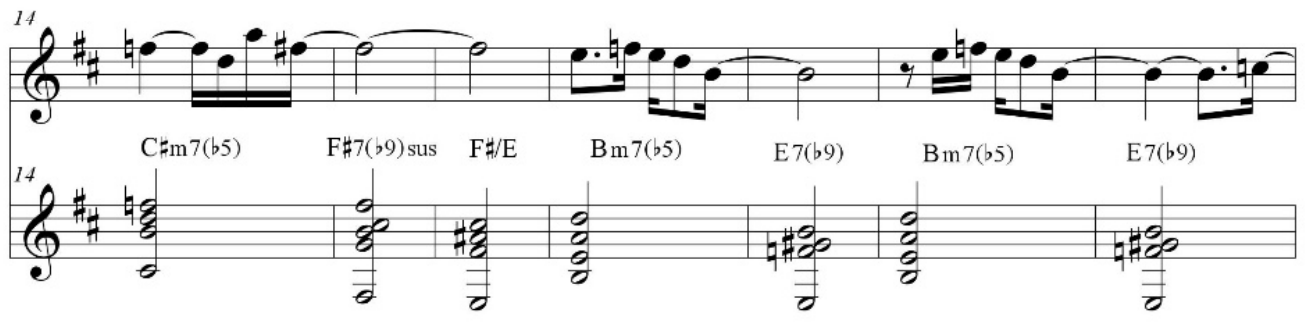

F1.
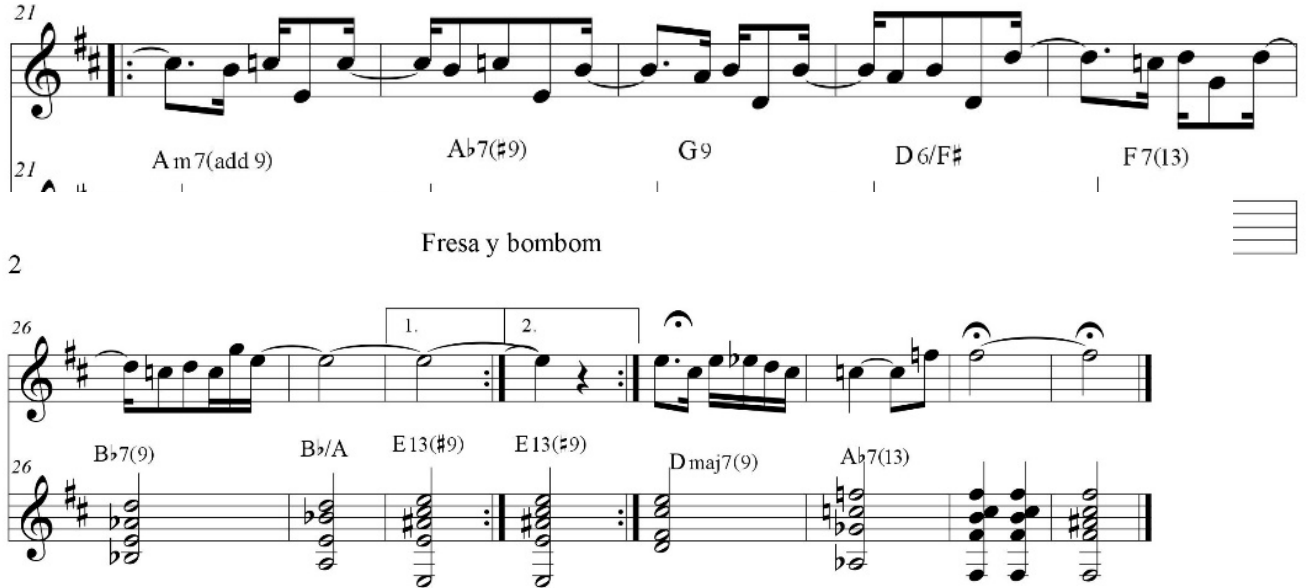
"Hola, Buenos dias!" O ritual se repetia rigorosamente igual. "Todo sob elcontrol?", perguntava Ignácio. O ventilador a meia distância, o rádio ligado, o café passado pousado ao lado do fogo para manter-se aquecido. A retidão ética e moral de Ignácio era típica de um revolucionário exemplar. Nada fugia do programado e do controle pessoal. Eu havia me esmerado por todos aqueles dias em repetir o ritual de organização que ele mesmo empreendia. A maneira como fechar a janela, onde guardar as louças, o cuidado em nunca deixar mais de duas guimbas no cinzeiro. De tardinha, tinha-se que acender a luz de fora, na varanda, e colocar as luzinhas de Natal da pequena árvore de plástico da sala na tomada. Era um ritual simpático e que trazia um sentido de familiaridade e acolhimento.

Naquela manhã eu havia combinado com Ignácio um café da manhã completo, com dois huevos revueltos. Achava fantástica aquela maneira de referir aos ovos mexidos. Era a mesma metáfora trabalhada por Alejo Carpentier em várias de suas ficções. Um furacão na frigideira: o processo revolucionário mexe as estruturas do ovo, misturando a clara e a gema. Para Alejo, havia uma conexão entre a metáfora do furacão para falar do processo revolucionário cubano e antilhano, e não apenas no século $X X$, mas desde a Revolução do Haiti - com os processos de transculturação afro-americanos característicos do empreendimento colonial ibero-americano. Por um átimo de segundo a expressão huevos revueltos trazia a imagem da utopia latino-americana ensejada pelo vanguardismo modernista de Carpentier e de muitos outros artistas e ensaístas da América Latina. Combinei com Ignácio e Carmen de tomarmos um vinho ao final da tarde. Queria tocar para eles a música que compusera por aqueles dias. Já estava na última semana de viagem e já havia feito diversas visitas à Fundación Alejo Carpentier e à Biblioteca Nacional José Martí. Ao fim da última visita de pesquisa na Fundación, Rafael presenteou-me com várias edições críticas das obras de Alejo publicadas pela Fundación.

Passara aquelas madrugadas escrevendo o ensaio "Afeto e método em Havana". A ideia era produzir um texto acessível e comunicativo para um público amplo, sem as 


\section{PRagMATIZES \\ www.periodicos.uff.br/pragmatizes - ISSN 2237-1508 (Ensaio)}

formalidades acadêmicas da escrita científica. A ideia era resgatar a aventura da imaginação sociológica, o gosto pela descoberta e pela experiência crítica, mostrando uma imagem verossímil de como a pesquisa científica na área das ciências humanas opera no limiar do prazer e do autoconhecimento. Eu adorava a maneira carinhosa como muitos cineastas cubanos se referiam aos filmes. A partir de uma contração da palavra película - falavam simplesmente peli. Como um princípio de prazer, um materialismo encarnado no próprio exercício do desejo, da imaginação e da liberdade criativa experimentada "na pele". Em sutil deslize, pela homofonia das palavras entre o português e o espanhol, passou-me desapercebido que a palavra "pele", em espanhol, se diz e escreve "piel". Apenas um falante de português poderia ouvir na contração peli o sentido dado pela metáfora "pele". Ri de mim mesmo pelo ato falho. Mas o "erro", aqui, era acerto e alimento por onde escapa o imaginário: a utopia da integração regional e a promessa de liberdade encenada no deslize ingênuo de um simples portunhol.

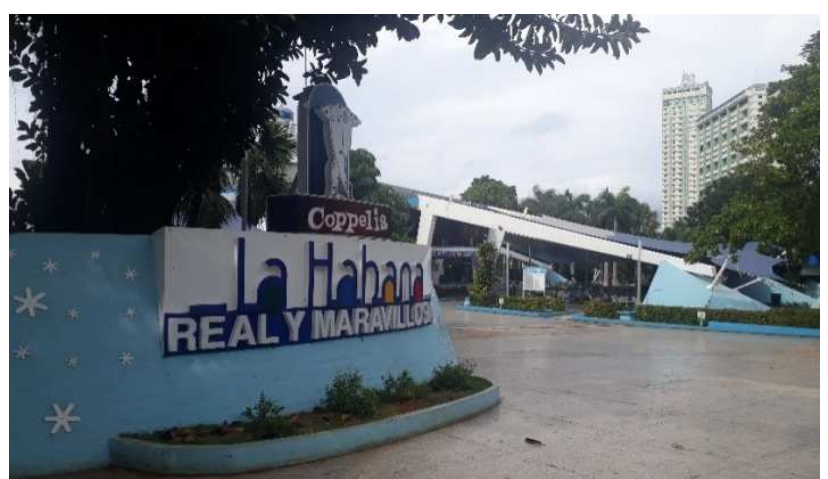

O conceito "real maravilhoso", de Alejo Carpentier, adaptado e popularizado como propaganda turística oficial pelos 500 anos de aniversário da capital cubana na porta da entrada principal da emblemática sorveteria Coppelia, em La Havana, entre a Av. 23 e L.

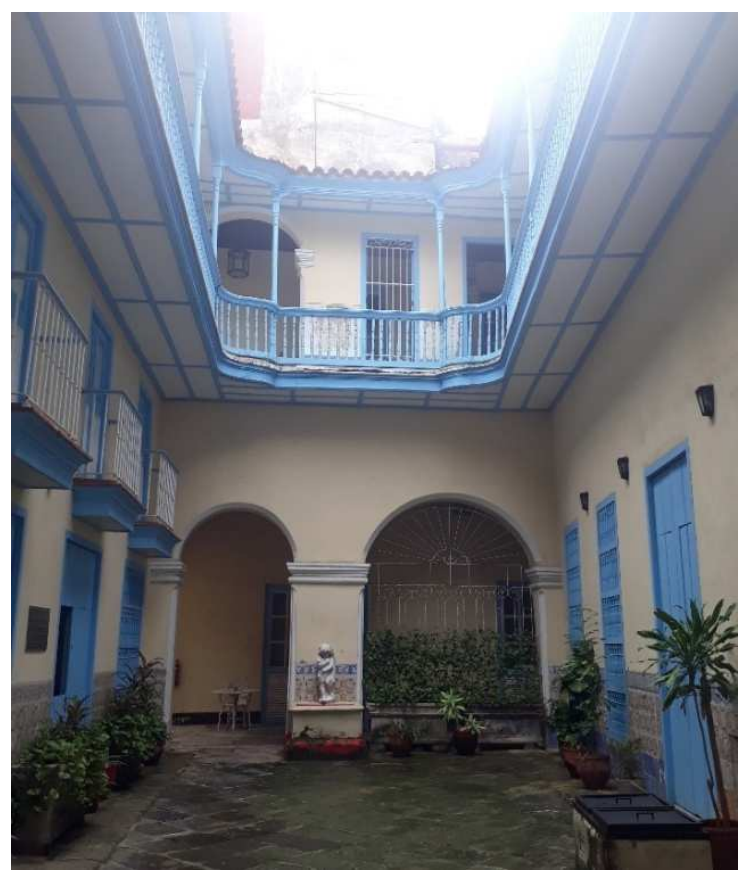

Pátio interno do casarão colonial que abriga a unidade de atividades culturais da Fundación Alejo Carpentier, situada na Calle Empedrado, em Havana Vieja, onde o escritor situou o cenário familiar de sua novela El siglo de lasluces (1962). 


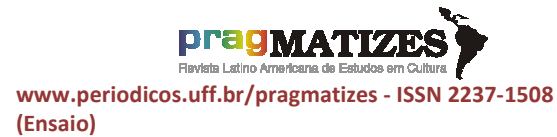

\section{Referências bibliográficas:}

CARMO, Maria Suzana Moreira do. "Fedra", de Jean Racine: moral do século XVII e criação literária. Letras, Santa Maria, v. 24, n. 49, p. 153-174, jul./dez. 2014.

CARPENTIER, Alejo. ¡Ecué-Yamba-Ó! São Paulo: Editora Brasiliense, 1989.

CARPENTIER, Alejo. El bairro de San Sulpicio. In: Crónicas. La Havana: Editorial Letras Cubanas, 1985, p. 399403.

CARPENTIER, Alejo. El encanto cosmopolita del Bairro Latino. In: Crónicas. La Havana: Editorial Letras Cubanas, 1985, p. 380-384.

CARPENTIER, Alejo. A harpa e a sombra. Rio de Janeiro: editora Bertrand Brasil S. A., 1987.

CARPENTIER, Alejo. Cartas a Toutuche. La Havana: Editorial Letras Cubanas, 2010.

CARPENTIER, Alejo. Concerto Barroco. São Paulo: Companhia da Letras, 2008.

CARPENTIER, Alejo. O século das luzes (1962). São Paulo: Círculo do livro, 1989.

GINZBURG, Carlo. Mitos, Emblemas e Sinais: morfologia e história. São Paulo: Cia. das Letras, 1986.

GINZBURG, Carlo. Relações de Força: histórica, retórica e prova. São Paulo: Cia. das Letras, 2002.

MALINOWSKI, Bronislaw. Prefácio. In: ORTÍZ, Fernando. Contrapunteo cubano del tabaco y el azúcar. Caracas: Biblioteca Ayacucho, 1987.

NEDER-CERQUEIRA, Marcelo. Explosão na catedral: Poder, Cultura e Modernidade na América Latina. Passagens. Revista Internacional de História Política e Cultura Jurídica, Rio de Janeiro, vol. 11, n. 2, p. 177-202, maio-ago. 2019.

NEDER-CERQUEIRA, Marcelo. Relações de força na passagem à modernidade na América Latina: cultura, poder e subjetividade. (Doutorado em História). Universidade Federal Fluminense, Niterói, 2016.

ORTíZ, Fernando. Contrapunteo cubano del tabaco y el azúcar. Caracas: Biblioteca Ayacucho, 1987.

PADURA, Leonardo. Máscaras. São Paulo: Cia. das Letras, 2000.

SCHNAIDERMAN, Boris. Maiakovski: evolução e unidade. In: SCHNAIDERMAN, Boris; CAMPOS, Augusto de; CAMPOS, Haroldo de (tradutores e orgs.). Maiakovski. Poemas. São Paulo: Perspectiva, 2008.

WISNIK, José Miguel. O que se pode saber de um homem? Piauí, n. 109, Rio de Janeiro [Editora Alvinegra], out. 2015.

ŽIŽEK, Slavoj. Como Marx inventou o sintoma? In: ŽlŽEK, Slavoj (org.). Um Mapa da Ideologia. Rio de Janeiro: Editora Contraponto, 1996. 